\title{
SOCIOECONOMIC PROBLEMS OF ETHIOPIAN YOUNG ADULTS AS REFLECTED IN THREE SELECTED ETHIOPIAN YOUNG ADULT NOVELS IN ENGLISH
}

\author{
Dawud Yibrie ${ }^{1}$, Haimanot Wassie 1 四 \\ ${ }^{1}$ Debre Markos University, Ethiopia
}

DOI: https://doi.org/10.29121/ijetmr.v7.i10.2020.767

Article Citation: Dawud Yibrie, and Haimanot Wassie. (2020). SOCIOECONOMIC PROBLEMS OF ETHIOPIAN YOUNG ADULTS AS REFLECTED IN THREE SELECTED ETHIOPIAN YOUNG ADULT NOVELS IN ENGLISH. International Journal of Engineering Technologies and Management Research, 7(10), 2865. https://doi.org/10.29121/ijetmr.v7 .i10.2020.767

Published Date: 16 October 2020

Keywords:

Socioeconomic Problems

Statement of The Problem

Objectives of The Study

\section{ABSTRACT}

The main objective of this study was to show the major socioeconomic problems of Ethiopian young adults in three selected Ethiopian young adult novels written in English. This study contends that contemporary Ethiopian young adult novels in English strongly represent contemporary socioeconomic problems of Ethiopian young adults which face in their day today activities. Eclectic approach was employed in this study so as to identify the major issues represented as challenges of young adults by using thematic analysis in the three novels, namely Breaking the Chain, Behind the Invisible Bars, and The young Crusader. This study comprises five chapters. Chapter one dealt with the background of the study which contains introduction, statement of the problem, research questions, objectives of the study, scope of the study, significance of the study, and limitations of the study.

Chapter two deals with the review of related literature where theoretical discussions of young adult literature, postmodern socioeconomic problems of Ethiopian young adults' and conceptual frame work of the study utilizes as a guide line are out lined. In the third chapter methodological issues are specified. The fourth chapter focuses on a thorough analysis of the three novels where thematic issues, choice of characters and narrative point of view were identified and explored. The major thematic issues as challenges of Ethiopian young adults' are viewed under the sections parallel themes and divergent themes. These include poverty, corruption, family problems, caring responsibility at early age, human trafficking organ harvesting, sexual abuse, teenage pregnancy and abortion, homelessness and loss of parents, alcohol and drug abuse, kidnapping, and new love. Choice of character(s) and third person narrative point of view in the selected young adult novels in English were identified as the styles of the authors to represent the real socioeconomic challenges of Ethiopian young adults in detail. In addition, using visual imagery and setting are identified as language feature used by the three authors. The thesis concludes with a chapter in which findings in the fourth chapter are summed up and generalization is made. 
Dawud Yibrie, and Haimanot Wassie

\section{INTRODUCTION}

\subsection{BACK GROUND OF THE STUDY}

Starting with literary works in Ge'ez language, Ethiopia is known for the emergence of literary works in Amharic and other vernacular languages. In addition to this, writing in English language is a tradition in Ethiopian literature. The valuable literary heritages reflect the indigenous civilization of the country. In addition to their significance in manifesting the indigenous civilization, the manuscripts written on religion, history, language, philosophy, astrology, social, economic, political and other issues have got a valuable contribution for research (Bayleyegn, 2011,p.5).

In fact for the purpose of this research, it will be important to consider only the emergence of the modern Ethiopian novel in English. As scholars agree, writing in English in Ethiopian literature was begun in the early 1960s. As Griffith (2000) described "the long -standing Amharic literary tradition has been a rich source of inspiration for the contemporary Ethiopian writers (novelists, poets, and play wrights) who write in English". In other words the exposure of these Ethiopian writers in English to the tradition of Amharic literature as a readership, coupled by their own experiences of authorship for some novelists in Amharic can be presumed to have contributed to their success in writing and publishing novels in English. Among those, Abbie Gubegna, Dagnachew Worku, and Sahle Selassie Birhane Mariam are reputed pioneer novelists both in Amharic and in English. In addition to those, among other pioneer authors in English, Ashenafi Kebede and Wolde Haile have each published a novel only in English (Ibid,p.7).When we consider the nature of the settings and themes embodied in these Ethiopian novels in English, most of them appear to feature the historical past, focusing on important events or/and personages drawn from the past socio-cultural and political reality. It indicates that Ethiopian authors convey issues of Ethiopians in their writings that dealt with the subject of the different historical periods in which those peoples of Ethiopia have passed through.

In recent years many authors follow the footsteps of previous writers in English. Among those writers Ethiopian young adult fiction writers in English can be mentioned. In Ethiopian literature, writing about teenagers or young adults in English is a recent phenomenon.

Scholars defined young adult literature as follows. Young adult literature itself is defined loosely as literature written for young adults and with a young adult protagonist (Christenbury, 2000; Milner and Milner, 2002). Also Donelson and Nilsen (2005, p.1) define young adult literature as "anything that readers between the approximate ages of 12 and 18 choose to read (as opposed to what they may be coerced to read for class assignments)".This shows that young adult literature is literature which is targeted to young adults approximately aged 12 to 18 and mainly focused on young adults as a protagonist character.

Scholars of young adult literature believe that the history and development of young adult fiction has been traced back to the second half of the 19th century. Erin Blackmore (2015) in her article "A brief History of Young adult Fiction" described the young adult literature has arguably existed since at least Laura Ingall's 'Wilder's Little House Series', which was published in 1930s. The publishers of the 1930s began to react by publishing literature that was too mature to be regarded as children's literature but not enough to be regarded as literature for adults(p.2). On the other hand, Cart (2005,p.75) presents that Maureen Daily's 'Seventeenth Summer', semiautobiography, published in 1942 is the title which approaches the genre of contemporary young adult fiction. Though written for adult audience, it became popular among teenage readership. Since then more of similar titles were released. It implies that writing about young adults was begun in the second half of the 19th century when writers published fictions concerning issues of teenagers.

Scholars of young adult literature suggest their opinions about the starting point of the contemporary young adult fiction. Watson, (2001, p. 775), as cited in (Andrea Ambróziová, 2011), for example claim that one of the first novels for the young adults was Beverley Cleary's 'Fifteen' published in 1956. On the other hand, Michael Cart (2005, p.784) for example claims that S. E. Hinton's novel 'The Outsiders 'published in 1967 is regarded as the first authentic young adult novel depicting the changes in the society brought by the 1960s.It seems that the newly established genre with its topics started to approach more the literature for adults then just to bridge the gap between children and adult literature. Most scholars of young adult literature agreed that the starting point of contemporary young adult fiction is 1967 which is associated with the publication of ' The Outsiders' by S. E. Hinton since it conveys the concerns of contemporary teenagers. 
The development of YAF shows that it comes across stages to be a popular genre. Ashley Strickland (2015) stated that the first golden age is associated with the beginning of writing about today's teens that parents recognize the experiences of teens. The young books of the 1970s remain true time capsules of the high school experience. But one these books devolved into 'single problem novels'---divorce, drug abuse---teens grew fired of the formulaic stories. The second golden age begins 2000, that the focus on culture and serious themes in young paved the way for authors to write with more candor about teen issues(Cart, 2005,p.785).This indicates that writers of this genre emphasized conveying contemporary issues of young adults so as to be realistic.

Good literature reflects the life and spirit of a people. Writers hold a mirror up to their society. A society finds expression through its author and in this way it is the co-author of literary works ....In its literature and art, a society reveals its 'soul' (Molvaer, 1997, p. ix).

It is with this definition of literature as written texts and with its social relevance articulated by Molvaer above that we pay our attention in this study to what we consider to be examples of young adults' literature from Ethiopia which are a mirror to Ethiopian young adults.

"Population censuses and projections conducted in different years show that youth constitute a high proportion of the Ethiopian population. For instance, according to the 1999 medium variant projection, Ethiopia's population was estimated at 63.5 million out of which 17.9 million or $28.2 \%(14.2 \% \mathrm{~m}$ ale and $14 \%$ female) were youth. According to the 2004 projection, the population will reach 73 million and the youth population will be $28.4 \%$ (14.4\% male and 14\% female) (MYSC, 2005).

But, as different sources indicate Ethiopian Young adults face many socio-economic challenges. Many struggle in one way or another for survival in environments that militate against them. Appalling pictures of deteriorating morality, senseless violence, widespread poverty, rampant teenage pregnancy, abortion and drug abuse, corruption, unemployment, human trafficking, disability, homelessness, difficult family relationship and friendship, caring responsibility, love, loss of parents etc. among the youth in Ethiopian families are what we see on a daily basis. In relation to this, Yared Gebremeden (2015,p.1) wrote an article "Some Global Issues Facing Our youth today" on Ethiopian Herald 26 December, 2015 describes now that we are well in to the new period having society which has begun to recognize serious concerns regarding issues that kids and youths have to deal with. One of the problem begins at home that is single parent, drug abuse, pregnancy, violence in schools, being material person, obesity, poverty, and the tendency to erode national pride /identity/ are the major socio-economic problems challenging the contemporary youth in Ethiopia as well as worldwide. Moreover, UNCIFE (2011) in its report "the state of the world's Children" addressed that the global challenges adolescents face in every part of the world. Among the prominent challenges adolescents face include violence and sexual abuse, early marriage, human trafficking, crime, drug and alcohol abuse, early pregnancy, unsafe abortion pose high risks for adolescent girls, HIV\&AIDS, unemployment, poverty, child labor, loss of parents, conflict with the law, and migration are highly influencing adolescents in this postmodern world.

Though it seems that we have reached a dead end, there is a feeling that the young adults' literature can be used as a tool to help the youth acquire skills and knowledge they require to forge ahead and overcome challenges in this society. Because the contemporary young adults' literature treats contemporary problems in ways that reflect the concerns of young adults as they struggle on how to become adults in a complex society. Ethiopian young adult novel writers in English tried to represent many socio-economic problems of the contemporary youth in their fictional works.

As a result, some Ethiopian authors have got the "Burt Award" in African literature for their writings on young adult issues. Eyob Getahun, "Behind the Invisible Bars"(2014),Solomon Hailemariam, "The Young Crusader "(2011) , Elishadai Tesfaye, "Waiting for the Sun”(2014), Kibrom G/Medhin," The Revelation”(2015), Kebere Mala "One Night in the Street" (2013),Daniel Negash "Breaking the Chain" (2014 ) e.tc , are known young adult novelists to mention few. These fictions reflect different challenges of the present Ethiopian young adult in real life situations. Therefore, the focus of this study is to identify the major socio-economic problems of Ethiopian young adults as reflected in three selected contemporary Ethiopian young adult novels written in English. These are Breaking the chain by Daniel Negash, Behind the Invisible Bars by Eyob Getahun, and The Young Crusader by Solomon Hailemariam 
Dawud Yibrie, and Haimanot Wassie

\subsection{STATEMENT OF THE PROBLEM}

On the introduction of modern education into Ethiopia, much attention has been given to the teaching of English in school and on the adoption of materials, texts, and books written in English. As a result, many authors have produced literary works written in English. The literary works of different forms reflect the historical, political, cultural and socio-economic conditions of Ethiopian people.

Literary works are portrayals of the thinking patterns and social norms prevalent in society. They are a depiction of the different facets of common man's life. Bayleyegn $(2011$, p.11) stated that a novel centrally includes the idea of representing the real world. It implies that literature represents the real world directly and /or indirectly.

As research shows young adult novels in 1980s and1990s bring the fantasy, horror, and mystery to the world, and the novels in the 21st century create trend setting and experimental novels to the young adult society. Young adult novels focus more on presenting new themes to young adults and start concentrating more on some serious issues (Lucy kawira, 2013, p.2). It signifies that YAF tends to represent realistic issues of teenagers. Similarly, Ashley Strickland(2015,p.2) in her article "History of young adult Fiction" described "the term 'young adult "was coined by the Young Adult Library Service Association(YALSA) during the 1960s to represent the 12 to18 age range. Novels of the time offered a mature contemporary realism direct at adolescents". On the other hand, Jenkins $(2011$, p. 135) as cited in Robyn E. Howell (2012, p.34) suggested that YAL is created especially for YAs, hoping to give them a more mature understanding of self and the world. The stories tend to have a sense of immediacy, rather than nostalgia, and their focus is on the experience of an individual, usually a teenage protagonist. It does not always provide the answers, but rather portrays a young person in search of them.

Furthermore, Lucy kawira (2013,p.2) described that Young adults ' literature addresses issues of peer pressure, abortion, poverty, corruption, love, money, loss of parents, disability, homelessness, human trafficking, and other challenges that young adults encounter as they are growing up. Ethiopian young adult fictions address the current socioeconomic problems of Ethiopian young adults. These are pertinent societal issues yet little has been done in the scholarly field to look at the issues explored and the value the books that are ever flooding in the Ethiopian market can have on the young adults. Researcher Beth Younger says:

Young Adult Literature reflects societal stereotypes, and although literary critics often ignore this genre, it remains an important body of work that deserves our attention for not only whom it entertains, but also for what it says about the human condition (Kaplan, 2003).

This shows that there is a dearth of study in young adult literature. The young adults in Ethiopia are attempting to transcend the social and economic evils that bedevil them and it can lead them to self- discovery. The researcher has found only two reviews on some Ethiopian young adult fictions as presented below.

GopalSharma(2012) in his article 'The issues of universality and contemporary Ethiopian fiction' tries to see love as a universal theme in African fiction in English and Ethiopian fiction in English. According to him the three young Adult novels namely 'Escape', 'the Letter', 'the Young Crusader', all are follow roughly the same 'trick' to end the novel. Escape by Gebeyehu Ayele ends when Dagne and Mulu meet together after escaping the clutches of their traditional and orthodox families. The Young Crusader by Solomon Hailemariam also shows us the same scene: 'Sofia moved closer to Admasu '. 'The Letter 'by Meron Tekleberhan is also a love story but with a difference which is the love between a teen-aged girl Ruth and her absent father (pp.72-75). He finds that the contemporary Ethiopian fiction in English is to present their concerns and problems first and then only try to depict a fictional world free from corruption, poverty, boredom, bondage and memories of coups dictators, and love as dominant themes. He concludes that though the Ethiopian fiction in English is one of the lesser known participants in the multitude of the African fiction scene, yet the new breed of writers will certainly make a mark (Ibid,pp.74-75).His review highlights the general themes of young adult fictions. But he doesn't show the major themes clearly as reflected in the novels. It simply focuses on how love is universal in Ethiopian fictions written in English. This makes it different from the present study, in that the present one attempts to identify the major socioeconomic problems of Ethiopian young adults in three selected young adult novels.

Another work related to the present study was Aschalew Kebede's review of 'The young Crusader' entitled by 'Book Review Addis Admass; The young Crusader' Published by "Addis Admass" Newspaper in "Art for Development" Section. According to this review, this novel thematically deals with the stamina/endurance demonstrated by Admassu, 12-grader hero of the book, to fight against and resist the corruption he faces in school, the locality and workplaces (Aschalew,2013, P,1). Furthermore, he found that the character in the book as 
representative of corruption, which manifests itself in a given society in a wide array of forms, instead of the character representing a single individual and new romance/love, to which emotions of all the young adults belonging to adolescence are attracted as a theme.

This review is similar with the present study in that this novel is selected as a subject of the present study. But Aschalew couldn't show how new love is a challenge in young adult life other challenging issues of Ethiopian young adults with relevant sources in the novel such as poverty, familial problems etc. As seen above, the reviews didn't include Eyob Getahun's 'Behind the Invisible Bars' (2014) and Daniel Negash's 'Breaking the Chain' (2014) in which the present study is targeted. Moreover, the present study attempted to identify the major socioeconomic problems of Ethiopian young adults in the three selected young adult novels by employing thematic analysis. Therefore, the present study would fill the gap existed in Ethiopian young adult literature in English.

The reason why the researcher is interested to study in this area is that: First, the availability of young adult fictions in English helped him to read some of them and he strongly believed that those fictions best represent the current socio-economic problems or challenges of Ethiopian young adults. Second, this area seams not well studied concerning thematic issues as far as the present researcher's knowledge concerned. Therefore, the present study would examine the selected Ethiopian young adult novels with a view to discerning the socio-economic problems of Ethiopian young adults thematically. It does not mean that this study is better than other studies if any.

\subsection{RESEARCH QUESTIONS}

The study would answer the following basic questions.

1) What are the dominant socio-economic problems of Ethiopian young adults conveyed in the selected young adult novels?

2) How are Characters depicted in the selected novels?

3) What are the poetic devices the three authors used as a style to represent challenges of Ethiopian young adults?

4) What are the common themes represented as problems of young adults in the selected novels?

\subsubsection{OBJECTIVES OF THE STUDY}

\subsubsection{GENERAL OBJECTIVE}

The main objective of this study is to show the major socio-economic problems of Ethiopian young adults as reflected in three selected young adult novels.

\subsubsection{SPECIFIC OBJECTIVES}

In line with its general objective, this study has the following specific objectives.

- To identify the dominant socio -economic problems of young adults represented in the three selected young adult fictional works.

- To examine how are characters depicted in the novels in question.

- To explore the poetic devices used as a style in the selected novels.

- To compare and contrast the similarities and difference among the novels representing problems of young adults.

\subsection{SIGNIFICANCE OF THE STUDY}

This study would have some benefits to different people. First, Students and some other people who are interested in reading young adult literature would be beneficial. It would help them to understand the major issues represented in contemporary young adult fictions and to know how young adult fiction writers represent the contemporary young adult life experiences. Second, the beneficiaries of this study would be other researchers who want to conduct a study on related topics with the present study. This study would help them being as a spring board in that it informs them some general concepts about young adult literature. 


\subsection{SCOPE OF THE STUDY}

Even though there are many young adult novels written in English which deals with different subject matters of young adults, due to some constraints such as time, finance, expertise, etc., this study only focused on identifying the major socio-economic problems of Ethiopian young adults. Particularly familial problems, poverty, corruption, caring responsibility, drug abuse and alcoholism, new love, homelessness, human trafficking, kidnapping, sexual abuse, and teenage pregnancy and abortion would be explored in three purposefully selected young adult fictions written in English language. These young adult novels are "Behind the Invisible bars " (2014) by Eyob Getahun, "The Young Crusader " (2011) by Solomon Hailemareiam and "Breaking the Chain" by Daniel Negash (2014).To examine the major socioeconomic problems, the three authors' choice of character(s) and point of view would be explored and eclectic approach is used in the analysis and interpretation of the major themes.

\subsection{LIMITATIONS OF THE STUDY}

In the process of conducting this research, the researcher had faced some problems. First, shortages of valuable and relevant sources were challenges in his work. To overcome this problem the researcher would use related sources from internet and other sources. Second, time constraint was also a major factor to accomplish this research in the available time table. In this case he prepared a time table for each work so as to manage time. Third, finance problem or budget constraint was the one that challenge him in this stud. So, the researcher had made coast breakdown and had tried to use the available finance to accomplish this study. Fourth lack of expertise was also another problem in conducting this paper. Therefore, the researcher consults his advisor in doing this paper.

\subsection{DEFINITION OF KEY TERMS}

In this research the following terms are defined as presented below.

- Poverty- defined as a condition where people's basic needs such as food, clothing and shelter are not met.

- Human trafficking-refers to the illegal practice of procuring or trading in human beings for the purpose of prostitution, forced labor, or other forms of exploitation.

- Sexual abuse-refers to undesired sexual behavior by one person on another.

- Alcohol addiction and drug abuse- any kind of drinking of alcohol or drug such as khat, arekee etc.

- Corruption-refers to a form of dishonest or unethical conduct by a person to gain personal benefit particularly bribery and embezzlement.

- Kidnapping- take someone away illegally by force, typically to obtain a ransom.

- Teenage pregnancy-is pregnancy in females under the age of eighten.

- Young Adult-a boy of girls whose age belongs to 12 to 18 year which is equivalent with Adolescent

- Socioeconomic problems -social and economic challenges which face Ethiopian young Adults

\section{REVIEW OF RELATED LITERATURE}

There are many ways to critically evaluate, examine and interpret literary fictional works. The social and economic problems of Ethiopian young adults are the consequences of social, economic, cultural, and political problems in which they live in. So young adult novels might be critically evaluated, examined, and interpreted from multiple perspectives or from multiple theoretical lenses. Due to this, the researcher would use an eclectic approach in this study. Thus, he believed that the general features and concepts of young adult literature would be used as a guide in this research.

This includes definition of young adult literature, trends and topics of today's young adult literature, its characteristics, and the concept and definition of socio-economic problems of Ethiopian young adults presented as follows. 
Socioeconomic Problems of Ethiopian Young Adults as Reflected in Three Selected Ethiopian Young Adult Novels in English

\subsection{DEFINING YOUNG ADULT LITERATURE}

To examine issues in Young adult literature, it is first necessary to define the genre. Many scholars define it in different ways, but they share the same view point. So, to define young adult literature, it is helpful to know why the title "young adult" is used and to which age group "young adult" refers.

Many adjectives have been used to label literature for young adults. It has been called any of the following: adolescent literature, adolescent fiction, junior teen novels, juvenile fiction, teenage books, and teen fiction (Christen bury, 2000; Donelson and Nilsen, 2005; Frey and Rollin, 2004). Scholars of young adult literature suggest approximately similar view points about what young adult is then. While "young adult" in the general sense often refers to people in their late teens and early twenties, the audience for young adult literature could be ages thirteen through twenty, ages twelve to eighteen, ages ten to twenty-five (Frey and Rollin,2004; Cart,2001; andDonelson and Nilsen,2005).This shows that the age range of young adults vary in different countries, discipline to decline etc., but in literature as a discipline the above mentioned categories can give a clue. The researcher take the 12 to 18 age range to represent Ethiopian young adults because this point taken as an average point by most scholars of young adult literature. And the researcher believed that young adult in this research is used interchangeably or synonymously with the term 'adolescent.'

Based on the above explanations of young adults in literature, Scholars defined young adult literature as follows. Young adult literature itself is defined loosely as literature written for young adults and with a young adult protagonist (Christenbury, 2000; Milner and Milner, 2002). Also, Donelson and Nilsen (2005, p.1) define young adult literature as "anything that readers between the approximate ages of 12 and 18 choose to read (as opposed to what they may be coerced to read for class assignments)". In Young Adult Literature: The Heart of the Middle School Curriculum, Lois Thomas Stover, adds to Donelson and Nilsen's definition of young adult literature. "Contemporary young adult literature is written for and about young people from the age of eleven, when most students enter sixth grade (the grade that frequently marks the first year of middle school), through the age of eighteen, when the majority of students graduate from high school"(2004, p.5). Similarly, Arthea Reed, author of Reaching Adolescents: The Young Adult Book and the School, agrees with Donelson and Nilsen that young adult literature is that which young adults read, and she includes "books written for children, adults, or a general audience that relate to the young adult's needs and interests"(2000, p.61). The editors of Classics Young Adult Literature, Charles Frey and Lucy Rollin (2004, p.2) do not include a specific date in their definition, but they believe young adult literature is "written or published with an audience of young readers [age thirteen to twenty].

Furthermore, Patty Campbell (2003) a critic of young adult literature, provides a more specific explanation for young adult fiction:

The central theme of most YA fiction is becoming an adult, finding the answer to the question, "Who am I and what am I going to do about it?" No matter what events are going on in the book, accomplishing the task is really what the book is about, and in the climactic moment the resolution of the external conflict is linked to a realization for the protagonist that helps shape an adult identity (quoted in Donelson and Nilsen,2005, p.36).

As seen from the explanations given above, the age range might vary in young adults. Even though the age range varies, young adult novels or stories primarily focus on the issues in which young adults encounter, their concerns, and the protagonist characters experiences.

Aronson says that classic coming-of-age stories capture 'the innocent passion of adolescence, when children sense the layers of human existence, experience the desires, and work out the ideals that will add depth to their character and provide them with a road map on their journey' (Aronson, 2010, p. 89).It implies that young adult literature emerged to represent the concerns of youths which focus on their experience and desire in their lives. It portrays teenage protagonists struggling challenges of their everyday life. Words of Carlsen (2001) will support to define exactly what young adult literature is:

Young adult literature is literature where in the protagonist is either a teenager or one who approaches problems from a teenage perspective. Such novels are generally of moderate length and told from the first person. Typically, they describe initiation into the adult world. Though generally written for a teenage reader, such novels like all fine literature - address the entire spectrum of life (p. 48) cited in (Padma Priya, 2016, p. 19).

This statement signifies that this genre of literature is typically focused on presenting issues in the eyes of teenagers. Though it portrays the life of young adults its readability reaches adults world too. Everyone who takes 
Dawud Yibrie, and Haimanot Wassie

on young adult novel would definitely have an insight to this world. This insight is a new perspective which young adult novels are known popularly.

Based on the overall explanations given above, the novels selected as a subject of this study are literary productions grouped under this genre, young adult novels.

\subsection{THE DEVELOPMENT OF PARTICULAR TOPICS IN YOUNG ADULT FICTION}

Young adult fictions become more realistic and appeal to teenage readers. Watson (2001) as cited in( Andrea Ambróziová 2011) the issues of interest to teenage readers in the 1960s and 1970s were " romance, relationships and difficulty of family life, pregnancy of teenagers, loss of family member or a friend" (p.19).In addition to this, Angew and Maureen Nimon (2000) claim that because of increased interest in novels featuring teenage sex and pregnancy, which were until that time a taboo in children's fiction, a number of authors began to write fiction about sexual abuse. They continue that only a couple of young adult novels were concerned with the reactions to the world of adults in which teenagers were forced to live. These novels were published mainly in the 1970s and 1980s. Besides "Young adult novels on political issues were rare, however, several novels on social issues were published. They dealt mainly with homelessness among teenagers. Other social issues depicted in young adult novels are drug addiction, running away from home, prostitution and teenage pregnancy" (Ibid, 20).As seen above, the topics of young adult literature shift through time. They try to focus more on current issues of the target audience rather than dealing with politics and other issues which was not the concern of teenagers.

In line with this, Koelling (2007) described that popular topics in 1970s and 1980s are those relating to internal teen life, family, social life, and the teen ethnic experience. Books "look at both extremes of contemporary teen life, from light, humor-filled tales of the ordinary daily life of adolescents to dark and painful stories of challenge and abuse"(p. 25). This indicates that the literature for young adults tends to portray current issues as realistically as possible. The issues are depicted on the background of the most natural environment for teenagers. This same author explained that "The shift in the seriousness of the topics is caused, with the changes in the society, and the general fiction in its effort to reflect reality as truthfully as possible does not avoid tough issues"(Ibid, p.28).It signifies that the topics of young adult fictions focus on the real life of youngsters in different situation. This portrayal of the life of the youth was related to the changes and developments of the society that general fictions reflect real lives and emotions of the society. In other words, the writing style of the authors shifted in parallel with the changes of the society. This leads a shift in the literary works that they seemed realistic since they convey serious issues and experience of young adults.

\subsection{CONTEMPORARY YOUNG ADULT LITERARY TRENDS}

The contemporary young adult literature incorporates new trends of writing. Koelling (2007, p.11) as cited in Andrea Ambróziová (2011) explored that during the period of 2000-2006 there were published 577 titles for young adults. These titles consist of genres such as: general fiction, nonfiction, poetry, mystery, humor, fantasy and science fiction. Out of these the general fiction presents $41 \%$ of all areas of literature for young adults. The major trends in teen literature included more books for older teens, adult authors writing for teens, the "feminization of teen literature, international authorship, noteworthy and innovative formats, and content trends. General fiction also known as contemporary realistic fiction forms 241 out of total 577 books (p.19). It means that it is $42 \%$ of books are in the general fiction category and form of the general fiction differs. There are traditionally narrated novels and short story collections, stories told in verse or in the form of diaries or letters, stories written in script, stories composed using more than one literary form, and stories told through dual or multiple perspectives. Stories told in the form of diary or journal entries or as letters have been more recent trend in teen fiction.

Furthermore, Cart (2005) claims that present young adult literature is a literature of contemporary realism which examines the realities of adolescent life. Authenticity, authorial honesty and relevance were required when the novel should be addressed to a young adult reader. The majority of the teen fictions mentioned on 'the Best Book of Young Adults' some were written as first-person narrative, followed by the third-person narrative. But there were also an increasing number of books written from multiple perspectives (p.128). It implies that, the most relevant factor for the readers as well as the authors is authenticity of the stories. This shows that authenticity of stories makes the contemporary young adult fictions realistic which can be said general fiction. Due to this they could 
Socioeconomic Problems of Ethiopian Young Adults as Reflected in Three Selected Ethiopian Young Adult Novels in English

be written in multiple perspectives. This trend also signifies Ethiopian young adult fictions as well. The next subsection presents the main features of contemporary young adult fictions in general

\subsection{ETHIOPIAN YOUNG ADULT NOVELS IN ENGLISH}

Ethiopia has a very long history of writing, and her literary tradition is many centuries old. The bulk of the country's literary production is in the indigenous languages, notably Amharic with its unique script. Although English is the medium of instruction both at the secondary and tertiary level, its use outside the class room is in significant. One can say that Ethiopian literature in English is still in its infancy.

But, still there are some authors who involved writing literary fictional works in English. Among these, Ethiopian young adult novel writers could be mentioned in the first place. "Following the footsteps of the classic novel Writers in English, several younger writers have appeared on the scene of Ethiopian literature in English. Be it the former authors or newcomers, they all wrote novels for adult readers. We don't find novels written for young people as targeted readers. Thus, the lunching of the Burt Award competition for Ethiopian literature in English is an opportunity that filled the gap. One can say that with the publication of Burt Award winning novels, modern creative writing for young adults is starting to trickle in to the realm of Ethiopian literature. It is hoped that the tradition will continue and pave the way for more authors to publish their works in English" (Zerihun Assfaw',2011) quoted in Solomon Hailemaram (2011, p.i).As it could be seen in this statement, Ethiopian writers in English began to produce novels targeted to young adults. This creates an opportunity to the targeted readers that they can easily engage reading these novels which are relevant and appropriate to their experiences. Furthermore, he explained that "the Burt Award literary competition has attracted both established and new Ethiopian authors. Those involved have attempted to write novels on issues that are pertinent to the target audience, young adults. It was encouraging to see 26 entries for the competition" (Ibid, i).

CODE-Ethiopia has done a commendable job during the past years in publishing books in local languages for high school children. Now through Burt Award it has embarked on a new venture, publishing novels for young adults. Selam Mussie (2013, p.1) writes an article on 'code, Burt News entitled 'Books for teens by Ethiopian Writers'on Addis Published an article about the 2012 winners the Burt Awards for African literature-Ethiopia' in its March 2013 edition. There is definitely some pride that comes with English fiction Written by native Ethiopian Writers. Especially for young readers who have no choice but read western high school stories with quite little to relate with fiction for young adults with familiar names, settings, and culture...would definitely be worth reading. The problem is that there are not many writers in Ethiopia who get to have the opportunity to publish their works for financial and many other reasons. However, the Burt Award for African literature is changing these dreams of writers into realities (SelamMussie,2013, p.1).

Burt Award for African literature is an annual literary Award offered in Tanzania, Ethiopia, Ghana, and Kenya to promote love of reading and encouraging young adult fiction writers of the respective countries and Africa all large. The award is sponsored by the Canadian Philanthropist William Burt and facilitated by local CODE organizations. Ethiopian Young adult novelists have got the Burt Award in Ethiopia in different years.

CODE in its article 'First Ethiopia Burt Award Celebrates Excellence in Young Adult Fiction' on Thursday, October 6, 2011 announces the first three recipients of the Ethiopia Burt Award for African Literature were announced at an official ceremony held at the Ethiopian Ministry of Education in Addis Ababa on August 27, 2011.

The first prize went to Solomon Hailemariam for his novel The Young Crusader, while the second and third prizes were awarded to Ato Gebeyehu Ayele for Escape and MeronTekleberhan for The Letters, respectively (CODE,2011). Retrieved March 12,2017 from. https://www.codecan.org/news/first-ethiopia-burt-awardcelebrates-excellence-in-young-adult-fiction

In addition to this, Robert Rayner (2014, pp.1-2) wrote an article on'code' Stories - for adults, young adults and children ,December 10, 2014 .This article presents that the second round winners were One Night in the Street, by Kebere Mala, The School News Paper, Linda Yohanes, and 'Children of Their Parents, by Befkadu Bekele'. The 2013 winners are: The Revelation, by Kibrom Gebremeden, Behind the Invisible Bars, by Eyob Getahun, and Breaking the Chain, by Daniel Negash.

These are some of the authors who Winn the Burt Awards in African young adult literature in the past recent years in Ethiopia. These young adult novels in English have great significance which promotes a love of reading. They primary concerned with the prominent challenges of young adults in Ethiopian society.

International Journal of Engineering Technologies and Management Research 


\subsection{CHARACTERISTICS OF YOUNG ADULT LITERATURE}

Young adult and adult fiction often overlap boundaries. Part of the difficulty, historically, with getting publishers and literary critics to acknowledge this literary genre lay in actually defining the genre. In fact, even today, well after young adult fiction has been recognized by many critics, there are many works of fiction which continue to vacillate between the two categories. However, there are certain characteristics that continue to appear and define the young adult genre.

Murray (2008) as cited in Robeny, E. Howell (2012, p.35) defined that YAF, "whether in the form of novel or short stories, has distinct attributes that distinguish it from the other age categories of fiction, adult fiction, middle grade fiction, and children's fiction. The vast majority of young adult stories portray an adolescent as the protagonist rather than an adult or a child". In addition to this, this same author described that YAL refers to "books written specially for a teenage audience the books usually have a young protagonist and present that young person dealing with issues that other young people all face (belonging, falling in love, or deciding what to do in the future ) or issues that young people are afraid they may have to face (violence, drug dependency, alcoholism, being alone, death of a love one, pregnancy, or divorce of parents"(Ibid,35).This indicates that young adult literature is different from other genres hence it has its distinct features such as the audiences and issues of this genre are mostly characterize teenagers.

Furthermore, Kenneth Donelson et al. (2013) summarized the following as some of the most significant characteristics as presented here with

\subsubsection{STORIES TOLD FROM THE VIEW POINT OF YOUNG PEOPLE}

Most young adult fiction is told from a first person perspective and is written from the eyes of a young adult. There may be multiple perspectives or plot lines in a single work, but they will all most likely be told from the perspective of a teenager. Essentially, teenagers like to read about other teenagers. Even if the story doesn't necessarily center on a young adult, it will often be told from a youngster's perspective.

\subsubsection{YOUNG ADULT STORIES OFTEN GET RID OF ALL ADULT FIGURES}

This often allows the young adult to shine in center stage and receive credit for all the work they accomplish throughout the story. Adults are often missing or only play a minor role. An incredible number of stories eliminate any and all adult figures. More often, any adults in a tale will be more of a mentor figure that the teen has sought out and approaches on their own terms.

\subsubsection{YOUNG ADULT LITERATURE IS FAST-PACED}

Many teens struggle to read for enjoyment at all, let alone willingly plow through a lengthy novel on their initiative. Most young adult fiction is quick to read and quick to develop. In order to accomplish this task, the young adult genre is often marked by a limited number of characters and narrative events. Furthermore, the language flows naturally, changes, and develops with the current times popularity in speech and trends is often important in young adult fiction.

\subsubsection{YOUNG ADULT LITERATURE INCLUDES A VARIETY OF GENRE AND SUBJECTS}

Young adults take interest in non-fiction, poetry, drama, science fiction, historical fiction, and even graphic novels, to name just a few. In fact, all types of literature are now being written to appeal to a young adult population. Teens' tastes vary just as much as adults; they like to read about a variety of subjects and issues in a number of different literary forms. On the same front, young adult authors can feel comfortable writing about other cultures or customs. Teens recognize that and can thoroughly immerse themselves in expanding their horizons. Indeed, 
Socioeconomic Problems of Ethiopian Young Adults as Reflected in Three Selected Ethiopian Young Adult Novels in English

educational research shows that the teen years are a great time, developmentally, for teens to learn about life outside of themselves.

\subsubsection{YOUNG ADULT BOOKS ARE OPTIMISTIC AND CHARACTERS MAKE WORTHY ACCOMPLISHMENTS}

Adults often get turned off by a teenaged protagonist that acts like they know more than adults, but in fact this is a major appeal to teens. The ability to succeed on their own terms and in their own way really appeals to young adults. In fact, change and growth is perhaps the most common theme appearing in young adult literature. All works of literature in this genre explore the theme to some extent. In most cases, the protagonist loses innocence as part of the passage from childhood to adulthood. This gaining of maturity would, potentially, affect them for the rest of their lives. The inherent need to learn, grows, and overcome appeals to teens of all ages.

\subsubsection{YOUNG ADULT NOVELS DEAL WITH REAL EMOTIONS}

At a time in life when hormones often rule, teens take particular interest in emotions and want to see them accurately represented in the fiction they read. Often books deal with similar emotional struggles: acquiring more mature social skills, achieving emotional independence from parents and other adults, developing a personal ideology and ethical standard, achieving a masculine or feminine sex role, etc. By following the development of these feelings in a fictional character, teens are often able to work out their own angst and emotional struggle(pp.25-28).

All these characteristics would definitely attract a young adult to read the novels. In fact a reader will not analyze these qualities before reading a novel. But definitely young adults would suggest a young adult novel by highlighting these characteristics after reading.

Owen Mary (2003) as pointed in A. Padma Priya (2016, p.159) explained YAL as:

YAL involves a teenage protagonist as the central character often reflects and interprets their views. One way to attract YA readers is to write through their eyes or to have a young narrator tell their version of a story, even if the story belongs to someone else (p. 120).

So far the characteristics of the young adult novels would give a map of how are the novels actually. The portrayal of teenage protagonist as the central character and involving the central character to narrate the story, in the language which young adult would understand is the special attention young adult novels have gained. Therefore, contemporary young adult novels give a space for young adults to involve themselves to face the realities of life. They would give the readers a new path to know the other part of their own life. Those features of young adult novels characterize Ethiopian young adult fictions which are selected as a subject of this study.

\subsection{POSTMODERN SOCIOECONOMIC PROBLEMS FACING ETHIOPIAN YOUNG ADULTS}

As the term indicates, Socio-economic problems are the combination of social and economic issues. Hajra Talat (2013) in his article "Defining socio-economic issues" stated that socio-economic issues include illiteracy, corruption, unemployment, child labor, health problems, the sarcasm of lack of basic necessities, live in miserable conditions, poverty, e.tc,. It might be possible to say that socio-economic problems are the social and economic challenges/problems / of an individual or a society as a whole encounter in their daily life.

In addition to this, Orana (2003, p.780) defines socioeconomic problems are "typical themes in literature deals with issues that are common to most people such as the loss of innocence, difficult family relationships, or a new love. Socio-economic themes deal with issues that concern a particular group of people, such as those in a certain neighborhood, geographical region etc., and these issues are usually specific in time and place, but they may echo in other cultures and times as well". Furthermore, this same author describes that novels and short stories of the period often portray "characters struggling against poverty, prejudice, corruption, and family problems" (Ibid, 781).This shows that socio-economic issues refers to the social and economic problems that people face in their life in which it needs the actions of the people to overcome these problems that might be poverty, corruption, family problems, new love and other concerns which affect them. Authors of young adult novels address those issues that young adults face and struggle against such problems which might appear in different circumstances. 
Young adults like other groups of the society face many challenges in their life. According to Mary land Macklin Library (2015) as cited in Padma Priya (2016, p.33), the contemporary socioeconomic problems young adults encounter are abortion, alcoholism, health problems/disability/, poverty, unemployment, violence, etc., that young adults face in life. In addition to this Yared Gebremeden (2015,p.1) on the article "Some Global Issues Facing Our youth today" on Ethiopian Herald 26 December, 2015 describes now that we are well in to the new period having society which has begun to recognize serious concerns regarding issues that kids and youths have to deal with. One of the problem begins at home that is single parent, drug abuse, pregnancy, violence in schools, being material person, obesity, poverty, and the tendency to erode national pride /identity/ are the major socio-economic problems challenging the contemporary youth in Ethiopia as well as worldwide.

Similarly, Lee Stanberry (2011,p.2) in his article "top Tenz issues facing our youth today" presented that single parent households, drug /alcohol/ abuse, growing up too fast, violence, being materialism, obesity, education disparity, poverty, identity, and other socio economic problems are the challenges of youthtoday.(RetrievedFebruary,12,2017fromhttps://www.com/file://E:/Top\%2010\%20Issues\%20Facing\%200 ur\%20Youth\%20Today\%20-\%20Toptenz.net.htm).

Furthermore, UNCIFE (2011, pp.57-59) described the global challenges adolescents face in every part of the world. Among the prominent challenges adolescents face include violence and sexual abuse, early marriage, human trafficking, crime, drug and alcohol abuse, early pregnancy, unsafe abortion pose high risks for adolescent girls, HIV\&AIDS, unemployment, poverty, child labor, conflict with the law, and migration highly influencing adolescents in this postmodern world (Retrieved March 13,2017 from https://www.unicef.org/adolescence/files/SOWC_2011_Main_Report_EN_02092011.pdf).

As seen above, there are many socioeconomic problems facing our youth today, which affects the wellbeing of young adults and the society as a whole.

In this research the socio-economic problems are defined as the social and economic problems facing Ethiopian young adults in their daily life. Some of the socioeconomic problems refers to poverty, corruption, caring responsibility, drug abuse and alcoholism, new love, difficult family relationship, homelessness, human trafficking, kidnapping, seeking job, sexual abuse, abortion and teenage pregnancy etc. in which Ethiopian adolescents encounter in their life. These issues are discussed as follows.

\subsubsection{CORRUPTION}

Corruption can be defined in different ways and it has different forms. Oxford Advanced leaner's Dictionary 7th edition defined corruption as "willing to act dishonestly in return for money or personal gain". In this research corruption is defined as the act of dishonest to gain personal benefit particularly bribery and nepotism. Bribery involves the improper use of gifts and favors in exchange for personal gain. Whereas Nepotism is based on favoritism granted to relatives in various fields, including business, politics etc., (Oxford Advanced Learner's Dictionary,2006). As one of the oldest and most perplexing phenomenon in human society corruption exists in every society. Acts of corruption are common in Ethiopia such as bribery, nepotism, and embezzlement.

\subsubsection{POVERTY}

Poverty is generally considered as a situation in which the under privileged do not have adequate food, shelter, lack access to education and health services are exposed to violence, and find themselves in a state of unemployment, vulnerability and powerlessness (Wubegzier, 2012,p.5). Poverty is multidimensional and has to be look at through variety of indicators such as levels of income and consumption, social indicators and indications of vulnerability to risk and sociopolitical access and participation. The most common approach to the measurement of poverty is based on income or consumption levels. So the researcher used the income level to discuss poverty. Thus, in this research it is defined as scarcity of basic needs such as food, closing, and shelter.

Poverty is the most prominent problem of Young adults face in Ethiopia. It is known that the peoples of the developing countries are victims of poverty including our country Ethiopia. 
Socioeconomic Problems of Ethiopian Young Adults as Reflected in Three Selected Ethiopian Young Adult Novels in English

\subsubsection{HOMELESSNESS AND LOSS OF PARENTS}

Orphan defined by Dictionary of English language 5th edition as "a child who has been deprived of parental care and has not been adopted, a child whose parents are dead" (Dictionary of English language online,2011). In addition to this, orphan is defined by the deprivation of parents, and is commonly understood to be a child who has lost both parents to death. However, historians and organizations such as UNICEF include the child who has lost one parent, often termed a "half" or "single" orphan, in the definition of "orphan" (UNICEF, 2008) cited in (BimalKanta Nayak,2014, p.1).

Orphaned children are one of the most disadvantaged groups, living in the community with various problems. Orphan problems are universal in nature and the magnitude of problem varies from one geographical location to another. There are over 14 million children living as orphans due to poverty, war, HIV/AIDS and other causes, and as many as 100 million more who are living homeless on the streets (Ibid, p.1).

As an effect of the poor conditions of this developing nation, Ethiopia contains and struggles to care for millions of orphaned children. Though estimates vary, recent approximations claim that there are over 5 million orphans including 1.5 million AIDS orphans in Ethiopia. The roles of caregiver and nurturer for the millions of orphans are mainly filled by orphanages. The high number of orphans is attributed to the loss of the both of parents due to HIV/AIDS, other diseases such as tuberculosis and malaria, high maternal mortality rate extreme poverty, famine, armed conflict child labor practice and mitigation almost six-teen percent of orphan population of Ethiopia which amount 5423459 is orphaned by HIV/ AIDS and 537510 of those orphans under age 18\% of Ethiopia house hold is caring for an orphan (the world bank; 2010) outside the family (Nayak,2014,p.6).

\subsubsection{DRUG ABUSE AND ALCOHOLISM}

The use of alcohol during the teenage or young adult hood years is a common phenomenon in many societies. According to Random House Dictionary, online (2017), drug and alcohol abuse refers to excessive use of a drug such as alcohol, narcotics, and addiction to drugs such as khat, and other drinks. Alcohol consumption at young age increases the risk of developing alcohol related problems later in life (Dana C. et al, 2016,p.3 ).A study conducted among high school adolescents in Ethiopia from 2001 to 2002 reported that about 8.9 percent drunk alcohol at least on weekly bases ,where as other reports among students in southern Ethiopia and private school in Addis Ababa found a prevalence of 7 percent and 19.2 percent respectively (Ayalu Reda et al,2012).This implies that adolescents in Ethiopia are using alcohol and other substances. Authors of different fictional works including adolescent /young adult/fiction addressed drug abuse and alcoholism as themes.

Angew and Maureen Nimon (2000) claim that after 1980s several novels on social issues were published. "They dealt mainly with homelessness among teenagers. Other social issues depicted in young adult novels are drug addiction, running away from home, prostitution and teenage pregnancy" (P. 20). This indicates that teenagers are vulnerable to different social evils that challenge their wellbeing including drug abuse and alcoholism. And these issues are depicted in Ethiopian young adult novels to address the target audience.

\subsubsection{HUMAN TRAFFICKING, ORGAN HARVESTING, AND SEXUAL ABUSE}

Human trafficking is an immense problem in Ethiopia. As a result of rampant poverty, large numbers of Ethiopian girls are voluntarily trafficked to other countries such as Sudan and Middle East through illegal desert routes. "The challenge the girls face during the journey is not the end but the beginning of the trauma" (Betre Yaqob, 2006,s.n.).This indicates that factors like poverty led young adults to voluntary human trafficking and that results they suffer different challenges during and after journey. "Trafficking in Ethiopia has occur internally and externally in the form of adults and child labor and sex trafficking. There were also some reports of organ harvesting and other closely related human right violations, such as exploitative inter country adoption (BetreYaqob, 2006,'Human trafficking'). Retrieved March 05, 2017 from http://www.assaman.info/...

Problem novels in young adult literature fall under the category of contemporary realism, the category of which the most popular young adult novels are a part. A problem novel is one in which the protagonist is faced with a 
Dawud Yibrie, and Haimanot Wassie

problem (ranging "from physical characteristics of puberty to sexuality, from pregnancy to parenthood, from rape to drugs") that he/she usually confronts on his/her own (Reed, p. 64).

It signifies that young adult novels portray young adult protagonists referred as problem novels or realistic novels.

\subsubsection{TEEN PREGNANCY AND ABORTION}

In different circumstances teenagers are at risk to unplanned pregnancy. As teenager is used synonyms with adolescent most of the time teenage pregnancy is defined as pregnancy in women under age 20, approximately. In this research teenage pregnancy is defined as pregnancy under the age of 18 in which 18 is considered as the legal mirage permitted in our country and the average age of giving birth in Ethiopia is estimated to 16 years. One current issue in young adult literature is teen pregnancy. Young adult novels about teen pregnancy can be very influential because teens "want to read about things that are interesting and true" (Donelson and Nilsen, 2003, p. 87). Teen pregnancy is also presented in Ethiopian teenager novels as a challenge of Ethiopian teenagers. Teenagers are vulnerable to unwanted pregnancy due to many problems.

Unintended pregnancy among adolescents represents an important public health challenge in many countries, especially in developing countries. The adolescent unwanted pregnancy is still increasing in Ethiopia (UNCEF, 2006). Population under 18 is about 39 million, of the total population estimated to 85, 2 million (MoH,2002 a) and 24 percent girls are giving birth before the age of 18(UNFPA,2005) quoted in (Georges Z. Nalenga, 2012, p.28). Several studies have shown that marriage of adolescents to became pregnant in Ethiopia rural area is 16 years. Teen pregnancies are of concern because they have negative health and socioeconomic consequences for parents, children, and for the communities as a whole. Moreover, regarding the socioeconomic consequences, adolescent girls leave home and begin conjugal life depending economically on men and adult work; and an early start to child bearing greatly reduces the educational and employment opportunities of women which is again associated with higher level of fertility. Many source indicate that unintended teenage pregnancy in Ethiopia results abortion both safe and unsafe abortion. According to the Ethiopian Ministry of Health, abortion accounts for 60 percent. And over half of 19 million women who annually seek abortion in Ethiopia are under 18(AYRH,2007) cited in (Sedgh et al, 2007,p.4)

Abortion is defined as a termination of a pregnancy by the removal or expulsion from the uterus of fetus or embryo, resulting in or caused by its death (Ibid, 5). Many girls turn to induced abortions to avoid unintended or unplanned births. Unsafe abortion can result serious negative health effects such as infertility and maternal death. Furthermore, abortion and pregnancy complications are widespread. For instance, in 2008 an estimated 382,000 induced abortions were performed in Ethiopia and an estimated 52,600 women were treated for complications of such abortions (Singh et al, 2010).These mentioned issues are amongst the prominent problems of Ethiopian teenagers that authors of young adult fictions represent to their readers.

\subsubsection{NEW ROMANTIC LOVE AS A CHALLENGE IN YOUNG ADULTS LIFE}

Love can be defined in different ways. Oxford Advanced Learner's Dictionary defined love as a noun "a strong feeling of affection. A strong feeling of affection and sexual attraction for someone" (Sally,2006). In the novels under study new romantic love is presented as a challenge in young adult life. It affects the wellbeing and daily activities such as their education. Psychologists believe that adolescence (12-18) years old is a particularly hard time for children. They are experiencing all kinds of new challenges in their bodies and in their feelings. As well, they often feel misunderstood as they are struggling to leave behind their childhood and become adults. Adolescence can be a time of both disorientation and discovery. This transitional period can bring up issues of independence and selfidentity, many adolescents and their peers face tough choices regarding school work, sexuality, drugs and alcohol, and social life, peer groups, romantic interests, and appearance tends to naturally increase in importance to sometime during a teens journey toward adulthood (Jeffery J. Arnett,2010,p.363-367).Adolescent experience many challenges due to the physical and biological changes. So, they embark on new issues like new love . 


\subsection{CONCEPTUAL FRAMEWORK OF THE STUDY}

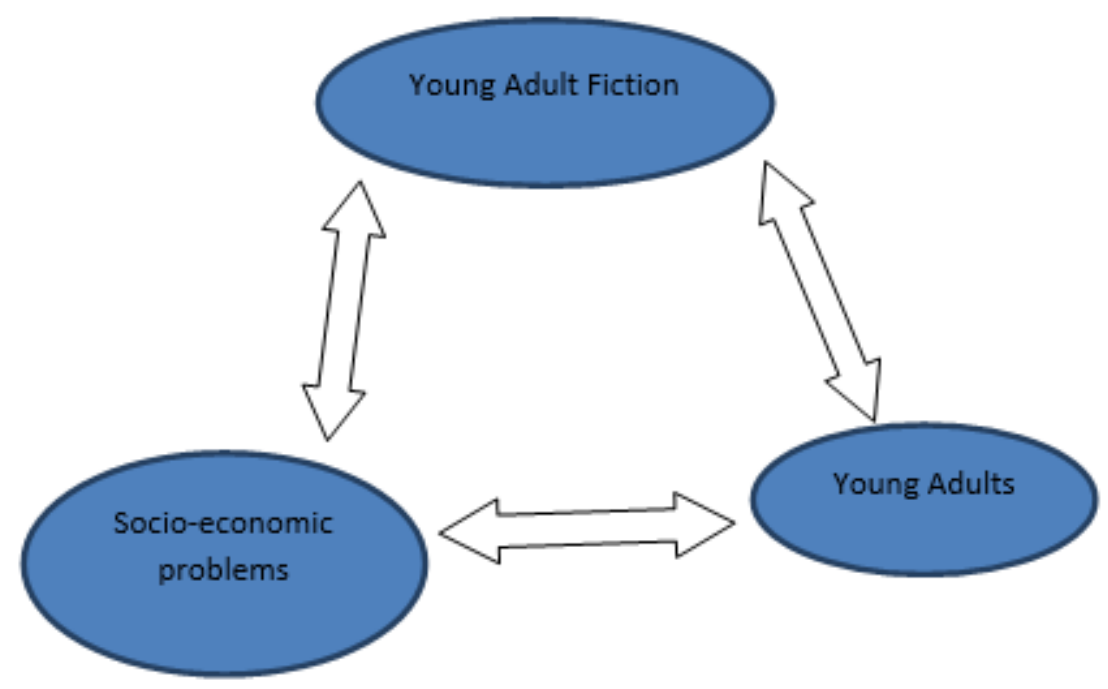

Figure 1

As shown above, the relationship between the text, socio-economic problems and young adults seems interconnected. The text contains the socio-economic problems. The arrows indicate that the socioeconomic problems reflected in a text represent young adults' life in a way that the life of young adults represented in a literary text.

\section{DESIGN AND METHODOLOGY OF THE STUDY}

\subsection{RESEARCH DESIGN}

The design of this research is purely a qualitative type. According to Denzin and Lincoln (2005) pointed in W. Creswell (2007, p.37) qualitative research begins with assumptions, a world view, the possible use of a theoretical lens, and the study of research problems inquiring into the meaning individuals or groups ascribe to a social or human problem. This shows that qualitative research helps to describe, analyze in terms of quality any given qualitative data using multiple theoretical lenses and worldviews based on the researcher's objective.

In this research, both primary and secondary sources of data were employed to get valuable information. The primary sources of the study were the three novels namely, 'Behind the Invisible Bars' (2014) by Eyob Getahun, 'Breaking the Chain'(2014) by Daniel Negash and 'The young Crusader' (2011) by Solomon Hailemarieam selected by purposive sampling. The primary sources would be critically examined, and described using close reading. Relevant data from the selected novels would be quoted, interpreted, and described to incorporate in this study.

This research is also benefited from secondary sources gathered from articles, journals, theses, books, and internet and website sources. The sources from those secondary sources have been incorporated in this study by paraphrasing, summarizing, describing, and quoting valuable and relevant data. The researcher selected the novels on the bases of: First, his reading experience of those novels helped him to believe that those fictions best reflect the socio-economic issues of Ethiopian young adults. Second, the novels are published in recent years so that they are not well exploited in Scholarly study.

\subsection{METHOD OF DATA ANALYSIS AND PROCEDURES}


Dawud Yibrie, and Haimanot Wassie

The researcher used thematic analysis. Thematic analysis is a method for systematically identifying, organizing, and offering insight into, patterns of meaning(themes) across data sets. Through focusing on meaning, thematic analysis allows the researcher to see and make sense of collective or shared meanings and experiences (Braun \&Clarke, 2006,p.86).This implies that thematic analysis is a flexible method that allows the researcher to focus on the data in different ways. In this research, to identify the thematic issues, the themes were grouped to some categories such as parallel themes and divergent themes in the selected novels. To do this eclectic approach is employed so as to critically identify the various socioeconomic challenges of young adults in the selected novels. Eclectic approach would help the researcher to explore the issues in multiple perspectives as much as possible because it would give freedom to use valuable approach fit to his study. Therefore, the concepts of young adult literature, trends and characteristics of young adult literature, the concepts of postmodern socioeconomic problems of Ethiopian young adults are used as frame works of this study as presented in the review of related literature part. The selection of extracts from each novel will be made representative of the whole novel as much as possible.

The researcher performed the following procedures while analyzing the collected data. First, he read the novels exhaustively until he got relevant data. Next synopses of the plots of the three novels are presented. Then relevant passages had been extracted. Then the relevant sources would be categorized such as parallel themes, divergent themes and sub themes. The extracted sources would be analyzed according to the categories made. Third, analysis of point of view, characters and in each novel was explored as much as possible. Forth the three novels would be compared. Finally, conclusion is made based on the works throughout this study.

\subsection{ORGANIZATION OF THE PAPER}

This paper has five main parts. The first part is the introduction which is the back ground of the study that includes the problem statement, research questions and objectives of the study, significance of the study, scope and delimitation of the study, and limitations of the study. The second section is the review of related literature which includes conceptual framework of the study. The review of literature contains definition of young adult literature, trends and development of particular topics in todays' young adult literature, characteristics of young adult literature, and concepts of postmodern problems facing Ethiopian young adults. The third section dealt with the research design, methodology and procedures which explain design of the research, methods of data analysis and procedures of the study in general. The fourth part focused on the analysis and interpretation of the selected novels which have some sub- sections as well. The fifth part dealt with the conclusion and recommendation section which was drawn from the works throughout this study.

\section{ANALYSIS OF THE THREE NOVELS}

\subsection{INTRODUCTION}

This chapter contains some sub-sections. Before the analysis, synopsis of the plots of the three novels namely 'Breaking the Chain, 'Behind the Invisible Bars,' and 'The Young Crusader, were presented. Analyses of themes are categorized as parallel and divergent themes to identify and compare the representation of problems of young adults in the selected novels. Under parallel themes, corruption, poverty, homelessness and loss of parents, and alcohol and drug abuse are discussed. The second sub- section dealt with divergent themes which include new love, human trafficking, organ harvesting, sexual abuse, teenage pregnancy and abortion, family problems, caring family responsibility at early age, kidnapping etc. are presented. The third sub-section explores the choice of characters and narrative point of view used as a style in the novels to convey the current socio economic challenge of Ethiopian young adults. Let us see each part of the analysis.

\subsubsection{SYNOPSIS OF THE PLOTS OF THE THREE NOVELS}

\subsubsection{SYNOPSIS OF THE PLOT OF 'BREAKING THE CHAIN'}


Munit lost her mother in death and her father had been abandoned his family. She is 16 years old lived in Addis Ababa near the migration office a village called Golasefer. Munit take care of her younger brother Ashenafi and the old grandmother. Ashenafi was a student and her grandmother become misbehaved that she drunk local drinks arekee and Teji regularly. She always asked Munit money to drink. Munit become the breadwinner of the family doing multiple works such as running the shop opened by her mother, look after her younger brother to continue his education, the house hold choresandher night school together. Besides the old drunker grandmother often raining insult on Munit.

Her aunt Zufan including her daughter and Ato Demsis hate Munit and her younger brother without any reason. Munit believed that they hate them because of their poverty and her hard work to overcome poverty. Eyerusalem insult her as if Munit is poor. One day Munit and her brother Ashenafi fought with Eyerusalem and her mother. They had been taken to police station with Ato Demsis. Ato Demsis was a developmental investor and he has personal relationship with the Instant Inspector that he has released without any question but Ahsenafihas prisoned. Munittry to confront the problem,but the Instant Inspector ordered the duty officer to avoid her from the compound. They hate and gave her nick names such as 'terror' of Gola, Munit 'kewti,' 'tomboy' ,'trouble maker', due to her struggle of injustice. This was not the only challenge she suffer.

The two human traffickers Tsegaye and Derd had disturbed her frequently coming to her kiosk. Munit had fallen in the hands of Dred when she found her brother from the compound of Tsegaye and Dried a place where trafficked girls, boys, and some young people hid. She met with Rihanna one of the trafficked girls and she heard from Rihanna all about the deeds of the traffickers and the suffering of boys and girl. The story ends when she run out and the prisoned of the two human traffickers that Munit announce their illegal act in the nearby media in collaboration with Ato Yilma a journalist who was strongly struggle such injustice in the area.

\subsubsection{SYNOPSIS OF THE PLOT OF 'BEHIND THE INVISIBLE BARS'}

Meron was born around Drie Dawa from wealthy family. Her parents were killed by Ato Fanta by car crash in secret that she also lost her sight during that time. This was done by her aunt Almaz and Ato Fanta to own the property of the wealthy family. This results Meron to be dependent and forced to live with her aunt.

Her aunt Almaz was 15 years old girl. She has boyfriend in that age. She often met with her boyfriend Goshu to chew 'khat' and drink alcohol. Almaz used to steal money from her father to chew ' kaht' and drink alcohol and quit school. Her father fired her from home. She conceived and made abortion.

Almaz and her husband had sold important equipment of Meron's parents and went to Addis Ababa since they bought a house and they made Meron a beggar in the streets of Addis Ababa and begun to hate and beat her without any reason regularly. Merom faced many challenges in the streets of Addis Ababa.Grum was born in Adama who lost his parents and become homeless and go to Addis. Life makes the two Meron and Girumn neighborhood and become friends. They began to help each other. But her aunt follows her suspecting that Meron might escape from them and they didn't want people to knew Meron. Even though he is a homeless orphan, Girum promised to Meron to escape her from her devilish aunt Alamaz and her husband Goshu. Meron kidnapped by Ato Fanta that he want to receive additional one million birr from Almaz after four years accepting bribe to kill Meron'sparent. Unfortunately, Girum took out Meron from the house Fanta hidden her that makes Meron escape from the invisible bars. .

\subsubsection{SYNOPSIS OF THE PLOT OF 'THE YOUNG CRUSADER'}

Admasu was a 12-grader student lived in Addis Ababa born from Ato Seyoum and woizero Nafkot. His family called him 'wofu' the nick name given by her grandmother in his childhood. One day the way from school he saw workers mix red dust brick with red chilli to sell it to people around Merkato in Addis Ababa. He reported to the nearby police station. The nearby police investigated the case and controlled the criminals. Admasu got admire that he do good in that the red chilli made from red brick can damage many people in the town.

Admasu was elected as president of the students' council. He strongly worked to solve wrong doings in the school especially the corrupt did of the director. The director enrolls new students by accepting bribes. Admasu has decided to talk with the director and went to his office. But the director insults him that it was not Admasus's concern. 
Dawud Yibrie, and Haimanot Wassie

But Admasu planned to discuss with other students and they believe that it is better to report to the parents committee and Admasu reported the issue and the director fired from work.

Admasu was fall in love with a girl named Sofia. He began to think about her everywhere even in the class room and he couldn't study at home. He couldn't sleep properly at night. Sofia also began dreaming about him, but hesitating to speak each other. It was challenging for Admasu and Sofia. They become confused and could not properly communicate with parent as usual.

At the same time Admasu's father was mentally sick and his mother decided to go India to further treatment to Ato Seyum. She decided to sell the house for medical treatment. Admasu forced to live with his uncle till his parents come back. His mother told him that they will suffer poverty when they come back. He decided to find some work to save money and found a job waiting his admission to university. He was employed as supervisor in private spare parts shop. But the workers were corrupt. One day they gave him some money to seem honest and to make him silent even if he found any wrong did in the shop. Through time they began insult and frighten him. He decided to quit work because the workers hate him. They reported to the owner as if Admasu is dishonest. They took original spare parts to their own and replace those cheap ones in the store and show the owner it was done by Admasu. In effects, Admasu become victim of intrigue and prisoned. The story ends when some workers were found as criminals and Admasu gained freedom and reunite with his parents came back from India. He became the young crusader struggling corruption, poverty, new love simultaneously.

\subsection{ANALYSIS OF MAJOR THEMES}

Theme in literature can be defined in different ways. "If you ask what a story is 'about', an author is likely to answer by telling you the subject. Indeed, many authors tell you the subject in their titles. Some refer to the central idea, the thesis, or even the message of the story, and that is roughly what we mean by theme; a generalization or abstraction from the story"(Jerome, B., Alison ,B.\&Hunter,2002,p.223).Theme refers to the main issue of a literary work in which the author want to address to the reader.

In the analysis of socioeconomic problems in the selected novels, the thematic issues are viewed how they are represented in the novels. The sociological and other demographic theoretical discussions are presented only to give insight. So, in this study we view the problems in relation to the literary representation of young adults' problems in the novels based on the theoretical discussions of young adult literature as presented in chapter two.

\subsubsection{PARALLEL THEMES}

The selected fictions convey some common themes that are challenges of contemporary Ethiopian young adults. These recurrent themes such as corruption, drug and alcohol abuse, poverty, homelessness and loss of parents are represented as challenges of young adults as discussed here with.

\subsubsection{CORRUPTION}

Corruption can be defined in different ways and it has different forms. Oxford Advanced Learner's Dictionary 7th edition defined corruption as "willing to act dishonestly in return for money or personal gain" (Sally,W.,2006). In this research corruption is defined as the act of dishonest to gain personal benefit particularly using the methods of corruption such as bribery and Nepotism. Bribery involves the improper use of gifts and favors in exchange for personal gain. Whereas Nepotism is based on favoritism granted to relatives in various fields, including business. As one of the oldest and most perplexing phenomenon in human society corruption exists in every society. Acts of corruption are common in Ethiopia such as bribery, nepotism, and embezzlement. Ethiopian young adult novelists conveyed this issue as a challenge in young adults' experiences. In the selected young adult fictions characters faced corruption in their day today activities. Regarding this Orana (2003) described that in young adult literature, novels and short stories of the period often portray "characters struggling against poverty, prejudice, corruption, and family problems” (p. 781). This implies that like poverty, prejudice and family problems, struggling against corruption is the concern of contemporary young adults.

In Solomon Hailemariem's novel, "The Young Crusader" Admasu, the protagonist character portrayed struggling against Corruption. Admasu was a 12-grade student. He faced corruption in work places and at school. He confronted 
the director of the school who enrolls new students by accepting bribes from people. Admasu was wondering about the issue that he has appointed as the president of the students' council. He planned to discuss with his friends about the issue to solve the problem hence the director of the school has ignored his report. "There are 54 students in Admasu's class room. He also realized that this is not an isolated case, for students were cramped in almost all the class rooms. Rumors in the school have it that the director enrolls new students disregarding the rules by accepting bribes." (Solomon,2011, p.29).

Here, the director of the school enrolls new students by accepting bribes. This made students discomfort in class rooms. It highly affects their educational process.

The director had insulted Admasu when he went to his office announcing the problem that the number of students in each class room is above the standard. The director replied that it was none of Admasu's business and told him that he couldn't come again to his office. But it has been affecting the teaching learning process and teachers couldn't manage the class due to that case. This shows that corruption is a societal problem which affects young adults, even it strongly affects them in schools because it can bring educational disparities if they did not fight against it.

In addition to this Admasu faced corruption in work place when he worked in private spare part shop. He has forced to prison by the workers that they made him victim of intrigue.

"You remember the money I[one of the worker] gave you twice? We gave you that money so that you would shut your mouth, if you saw anything in the shop. We will regularly give you your share but you have to keep your mouth shut. If you open it as now, then that will be the end of your life".

"That is right! If you say a word to the owner, we will kill you". Admasu felt helpless. At that moment the owner's car pulled up in front of the shop.Everyone started behaving as if nothing had happened"(Solomon,pp.145-146).The workers attempted to fire him from work because they were cheating the owner for their own business by changing the quality materials by fake ones. They gave money to Admasu being as if they encourage him. But he was not happy. In such away he decided to quit work. When the owner comes, some of the workers pointed that Admasu was dishonest and he steal some packets and changed by cheap ones. They show the changed packets on the shelf. The owner began to find Admasu with police officers. Then Admasu took to prison and charged50,000-birr criminal. But police investigated that he was not a criminal rather he was a victim of intrigue that the workers gave witness against him were committed the crime. In this novel, the characters who portrayed as corrupt were representatives of corruption in which corruption is widespread in the country. The 'spare part shop' metaphorically represents the country Ethiopian that many people dishonestly corrupt and exploit the valuable resources and the corrupt individuals represent corrupt people, whereas Admasu represent people who are not involved at corrupt deeds. Thus, the young adults had faced this problem in their daily life while they struggle to work hard like Admasu.

Similarly, Daniel Negash also addressed corruption as a challenge of young adults' in 'Breaking the Chain'. The main character of this novel, Munit was struggling against corruption that she faced when she had gone to police station fought with both her aunt Zufan and her daughter Eyerusalem. It could be seen as demonstrated bellow.

"Oh my God!" said the assistant inspector when he saw Ato Demsis. "Are you ok? Is anything wrong?"

"Dammit! I was humiliated by a bunch of riff-raff who attacked my wife, my daughter and me. And this happened at my place, in front of my gate!

"...Calm dawn and give me the details. I will fix the entire problem immediately. Please, be seated."

"Let me remind you one thing for the past time;" Ato Demsis continued tapping nervously at the table with his big gold ring. "You are one of the boys in the chain. If something goes wrong my business will be the first victim. My friend, keep this in mind! All the time! I hope you understand".

"Good, I want you to take measures against this girl and her brother. Am I clear?"

"Yes sir," said the assistant Inspector saluting him.

"Great! Full compliance is highly rewarded. I may even contact your superiors to get you promoted. How does that sound?"

"Whatever you think is right, sir!"

"If you need anything, contact Mogie or Dred. I will inform them. Good bye." They shook hands and Ato Demsis walked out of the office and then out of the compound.

Munit turned around and faced the duty officer.

"What is going on?" Why is he leaving when we are detained? Is this fair? Aren't we all equal before the low?"(Daniel,2014,pp. 34-35) 
Dawud Yibrie, and Haimanot Wassie

These extracts show that the Instant Inspector and Ato Demsis have a personal relation. The Instant Inspector let Ato Demsis to go home without any investigation. But Munit's brother Ashenafi stay in custody. Munit tried to confront that it is not fair but she couldn't. "Let me remind you one thing for the past time;" Ato Demsis continued tapping nervously at the table with his big gold ring. "You are one of the boys in the chain. This statement indicates that they did such corrupt things together. The "chain" here signifies that Demsis has many friends including the Instant Inspector. Demsis is a developmental investor that he has friends working as human trafficker including Tsegaye, Mogei, Dred, and the Instant Inspector. So, it might be hard for them if the instant inspector didn't work hard against Munit and her brother in that they may exposed to the public. There is also a clue that the officials are exploiting the poor ones like Munit. Demsis here portrayed as a developmental investor who have power to do what he need through corruption. Here, corruption is performed by two methods that are bribery and nepotism. This is fact that many people in our country experience such problems by dishonest officials and individuals. This is what the author try to convey that young adults are facing and struggling corruption as part of a society.

Unlike in 'Breaking the chain' and in 'the young crusader, Eyob Getahun, in 'Behind the invisible Bars', highlighted corruption that was performed in the way that people harm others to get money. Ato Fanta and Almaz had decided to kill Merom's parents. Almaz promised to Ato Fanta that she would give him 250,000 birr if he could do the murder. He did the secret by crashing their car by a big tracker when they were going to Harar in which their construction site was found.

"If I knew that you feel this way, I'd have given the assignment to somebody else. By the way, how could you recognize her? I was confident that nobody would recognize her. That was why I got the confidence to make her a beggar."

"You're extremely successful in disfiguring her," he smiled sarcastically.

She too smiled.

"What did you do to her? If not the scar on her wrist, I wouldn't have been able to recognize her."

"The scare?" the woman sounded shocked.

"I wouldn't have recognize her if I hadn't seen that scar".

"Really?"

"Yeah, but most of all, I've been looking for you desperately as I thought I should be paid more for what I did."

"I have already given you two hundred fifty thousand birr," the woman barked angrily.

(Eyob,2014,p.83).

This dialogue indicates that Almza and Fanta did the secret in that Fanta accept bribe from Almaz. As the statement shows they seem became quarreling each other. Fanta seemed became regret what he did against Meron's parent despite he want some additional money for that matter. He became an obstacle to Almaz. Even he began to ask what Almaz did against Meron. This situation evokes fear to Almaz. She didn't think that Fanta would break the promise they had had.The textual evidence shows that young adults lost their parent by the cause of corruption. As the story go through, Meron kidnapped by Fanta and Almaz promised him to give one million birr that leads the death of Fanta and Almz's fall under custody. This implies that young adults like Almaz fall in risks due to their involvement in corruption. Thus, all the above textual evidences indicate that corruption is affecting Ethiopian youth and this implies that corruption is becoming widespread in this country. Also, it shows the resilience of Ethiopian young adults to struggle corruption as Munit in 'Breaking the chain' and Admasu in 'The Young Crusader' had.

\subsubsection{POVERTY}

Poverty is generally considered as a situation in which the under privileged do not have adequate food, shelter, lack access to education and health services are exposed to violence, and find themselves in a state of unemployment, vulnerability and powerlessness (Wubegzier, 2012, p.5). Poverty is multidimensional and has to be look at through variety of indicators such as levels of income and consumption, social indicators and indications of vulnerability to risk and sociopolitical access and participation. The most common approach to the measurement of poverty is based on income or consumption levels. So the researcher used the income level to discuss poverty. Thus, in this research it is defined as scarcity of basic needs such as food, closing, and shelter.

Poverty is the most prominent problem of Young adults face in Ethiopia. It is known that the peoples of the developing countries are victims of poverty including our country Ethiopia. Accordingly, young adult novel writers 
Socioeconomic Problems of Ethiopian Young Adults as Reflected in Three Selected Ethiopian Young Adult Novels in English

in Ethiopia tried to convey poverty as a challenge of young adults. For example, Solomon Hailemariam, in his novel in 'The Young Crusader' had addressed this issue.

In 'The young crusader', the economic class is portrayed as middle class society who have at least shelter. But, there are clues that convey characters are living in scarcity of money to full fill their basic needs such as cloth and other needs. Admasu's uncle' has small income where his families were suffering poverty. His uncle has six children, more than he could support. Besides, whenever Admasu buys something, his uncle's children would ask their father to buy the same thing for them. But, Nigatu refused to do because he couldn't afford to satisfy the demands of his children.

"You always said that, father. I asked you the same question twice a few months back and you promised to buy me soon. Look at this shoe Dad. You can see my toe. I am tired of wearing this shoe. I need a new pair of shoes."

'My son, I have been saving hard to buy you shoes, but your sister was so sick and I had to take her to hospital. I used the money for her medication. You should understand the family situation" (Solomon,2011,p. 93).This statement show that Ato Nigatu couldn't' afford the need of his family due to the fact that they live in hand to mouth (in poverty). The boy repeatedly asked his father if he bought a shoe, but his father told him that it is not possible. Even though he accepted the question and tried to save hard, he paid the money for his daughter's medical treatment. 'My son, I have been saving hard to buy you shoes 'conveys that it was very difficult to save the amount of money needed for buying his son's shoes. Furthermore, father reminded his boy, to understand the situation of the family. This implies that there is scarcity of money to meet ends in this family that is way the father told his boy to understand the family situation.

In addition to this, the protagonist character Admasu was working at an internet café that his mother told him that they will be in poverty when they get back from India. They had sold their house. His mother told him by her email letter, they will suffer poverty even they have no a house to settle other than asking his uncle to live together in one house.

"Your father is doing so well that he is now asking to be discharged from the hospital and return home. Therefore, I will have to withdraw the entire saving to settle the hospital expenses. The doctors, however, insist that he should stay a little longer in the hospital. We must leave the hospital soon as we are about to run out of money, whether the doctors insist or not.

When your father and I return home, life will be difficult for some time. But sooner or later we will be all right. I can't wait to see you" (Ibid,111). This show that Admasu's mother faced scarcity of money and become worried about their future life after come back from India. She decided that they must leave hospital even though the doctors insist that Seyoum must wait for some time in hospital. The message of Admasu's mother leads Admasu to think something and planned to work and earn money that result to him suffer challenges of life.

In 'Breaking the chain', Munit had worked hard to fed her brother Ashenafi and old grandmother woizero Ayelech. And also her father had borrowed money from Demsis for medical treatment of his wife. This result Ato Worku to be abandons his family. Munit struggled to overcome poverty. Eyerusalem the daughter of Demsis insulted as if Munit is poor. The only property she has is the kiosk found near the migration office.

"Hey, las do you have a mobile card?" Eyerusalem asked. Like her mother, she never called Munit by her name. To them, she is a nonentity. Munit always ignored them until they called her by her name. Munit stared at her angrily.

"Oh, tigress! You scare me looking at me like that," she said covering her face with her hands.

[...] "She is your grandma too [Eyerusalem]; you shouldn't neglect her. By the way, don't try to put on airs when you talk to me. You're nobody! It's funny that a poor girl behaves thus and acts wild. I'd rather you showed concern to grandma."

"What? [Munit] Where are you been all this time? Don't pretend to be concerned! I know that you wouldn't allow her to pass one night in your house. 'Poor!' I may be poor but I am fending for me and my family. And don't forget poverty is not hereditary. You will see, it won't be long before I break this chain of poverty!”(22).

Munit is working hard even though she is unlike Eyerusalem. Eyerusalem and her family didn't treat Munt as human being rather hates her. They call her 'las'. This is verbal abuse that Munit suffer due to her poverty. It implies that people who are rich look others as weak and insult them rather than encouraging them to struggle poverty. This is what we see most Ethiopian youth face. Munit live in hand to mouth. She supports her younger brother and her grandmother working at her kiosk. She hopped that she would break the chain of poverty. This shows that young adults are facing poverty and they are struggling to overcome this challenging problem. 
Dawud Yibrie, and Haimanot Wassie

In addition to this, in this novel poverty is described in many ways. It is addressed through characters' that they portrayed as migrants to Middle East. Female and male young adults forced to migrate to Middle East particularly Arab countries that results young adults to be victim of violations including local human trafficking, denying money, sexual abuse, child labor etc.Characters like Rihanna, and others are portrayed as victims of the mentioned problems. In addition to poverty, the common issue in the selected young adult novels is homelessness and loss of parents that many children and adolescent face in Ethiopia.

\subsubsection{HOMELESSNESS AND LOSS OF PARENTS}

Orphan defined by Concise Oxford English Dictionary 11th edition as "a child who has been deprived of parental care and has not been adopted, a child whose parents are dead" (Concise Oxford Dictionary online, 2017). In addition to this, orphan is defined by the deprivation of parents, and is commonly understood to be a child who has lost both parents to death. However, historians and organizations such as UNICEF include the child who has lost one parent, often termed a "half" or "single" orphan, in the definition of "orphan" (UNICEF, 2008) cited in (Nayak,2014, p.1). Children lost their parent in many cases. Thus, they become orphans and suffer many hardships in life.

Orphaned children are one of the most disadvantaged groups, living in the community with various problems. Orphan problems are universal in nature and the magnitude of problem varies from one geographical location to another. "There are over 14 million children living as orphans due to poverty, war, HIV/AIDS and other causes, and as many as 100 million more who are living homeless on the streets" (Ibid, p.1).As an effect of the poor conditions of this developing nation, Ethiopia contains and struggles to care for millions of orphaned children.

Though estimates vary, recent approximations claim that there are over 5 million orphans including 1.5 million AIDS orphans in Ethiopia. The roles of care giver and nurturer for the millions of orphans are mainly filled by orphanages. The high number of orphans is attributed to the loss of the both of parents due to HIV/AIDS, other diseases such as tuberculosis and malaria, high maternal mortality rate extreme poverty, famine, armed conflict child labor practice and mitigation almost six-teen percent of orphan population of Ethiopia which amount 5423459 is orphaned by HIV/ AIDS and 537510 of those orphans under age 18\% of Ethiopia house hold is caring for an orphan (the world bank; 2010) outside the family quoted in(Ibid,p.3). This research doesn't attempt to show such figurative examination regarding homelessness and loss of parents rather to show how the selected novels convey themes of orphan and loss of parents as challenges of the current Ethiopian young adults.

Young adult novels represent orphans' life in Ethiopia as they are part of a community. Young adult life as orphans and homelessness is a theme in adolescent literature because it is a prominent problem in Ethiopia. Many young adults forced to live in streets that they lost their parents. In Eyob's 'Behind the invisible Bars', characters are portrayed as orphans. Girum a thirteen year old boy lost his mother dead of cancer. His father's income was too small to meet ends. They began to live in poverty. His father decided to took Girum and Sosina to the orphanage in Addis. The orphanages told him that they would only took Sosina Girum's younger sister. Girum turned back to Adama with his father. One day he went to Addis and began to live in the streets. After two months his father has dead. This leads Girum to be a street child.

"Girum carelessly gazed at the stream of passerby, resting his elbows on his knees, and cupping his cheeks in his hands. Unlike most of the people in the street, he didn't have a home to rush to; neither did he have a family to miss. He was a homeless orphan. In fact, at the moment, he was not worrying about home or family. Rather, he was listening to the rumbling of his empty stomach. He didn't eat the whole day" (Eyob, 2014, p.2).

The story here signifies that Girum has been starved, homeless and has no family where he had to go and miss. Even he didn't eat the whole day. Grum's mother was the pillar of the family since his father's pension was too small. She fed her family baking 'injera' and sold to customers. "Losing my mother was difficult; losing both my mother and my sister was unbearable. "I lost all my family. I decided to come back Addis Ababa for I had a friend named Bedlu. And I have been living in the streets of Addis Ababa ever since. That for about five years, I guess, my friend and I used to steal" (Ibid, 48).Girum went to Addis hence he lost his parents. He began to live in the streets of Addis Ababa with his friend Bedlu. Girum and Bedlu have no option other than stealing to survive in the streets. The author here portrays Girum and Bedlu to represent young adults living in the streets of Addis Ababa who come from different regions of the country being orphans. They suffer hunger and live in dark life with no help. Thus, loss of parents is a challenge in Ethiopian young adults that results to be dependent and being beggars and thieves. 
In Daniel's 'Breaking the chain', the boys live around the minibus and taxis station and the girl who has taken by local traffickers were portrayed as orphans and homeless. Munit found the small boys around the minibus stations as they were homeless when she found her brother Ashenafi around the area where he was working as a fare collector in Kidane's taxi.

"Does Ashenafi smoke and chew khat like you?" [Munit].

"Ashu, the owl, has no reason to. He's not like us. He sleeps in a house. He's lucky. He doesn't even eat 'bule' like us" (Daniel,2014,p.59).This dialogue shows that the boys are orphans. 'He is not like us' signifies that their life is different from Ashu implying that they lost something like shelter, food, help etc.

This made them addicted to smoking and chewing khat. As they are homeless, they eat 'bule' or leftover food from hotels unlike Ashenafi. It indicates that many boys who are homeless suffer hunger and as they have no options they chose to use drugs to survive. This is what many adolescents face in this post -modern period. The unnamed boys who had talked with Munit represent the boys who live in the same condition in the streets.

\subsubsection{DRUG ABUSE AND ALCOHOLISM}

The use of alcohol during the teenage or young adult hood years is a common phenomenon in many societies. According to Random House Dictionary.com (2017), drug and alcohol abuse refers to excessive use of a drug such as alcohol, narcotics, and addiction to drugs such as khat, and other drinks. Alcohol consumption at young age increases the risk of developing alcohol related problems later in life (Dana C. et al ,2016,p.3 ).A study conducted among high school adolescents in Ethiopia from 2001 to 2002 reported that about 8.9 percent drunk alcohol at least on weekly bases, where as other reports among students in southern Ethiopia and private school in Addis Ababa found a prevalence of 7 percent and 19.2 percent respectively (Ayalu Reda et al,2012).This implies that adolescents in Ethiopia are using alcohol and other substances. Authors of different fictional works including adolescent /young adult/fictions addressed drug abuse and alcoholism as themes.

Angew and Maureen Nimon (2000) claim that after 1980s several novels on social issues were published. "They dealt mainly with homelessness among teenagers. Other social issues depicted in young adult novels are drug addiction, running away from home, prostitution and teenage pregnancy" (P. 20). This indicates that teenagers are vulnerable to different social evils that challenge their wellbeing including drug abuse and alcoholism. And these issues are depicted in Ethiopian young adult novels to address the target audience. In the three novels understudy, some characters are portrayed as alcohol, cigarette, and khat addicted in which young adults face in Ethiopia. In Eyob's 'Behind the invisible bars', Almaz and her boyfriend were addicted to alcoholic drink, smoking and chewing khat.

"Almaz had a boyfriend she met while selling tella and arekee with her mother in their shack. She continued to see him. She stole money from my [Meron] grandfather to drink alcohol with her boyfriend.

Grandpa heard from my father who used to be in the same school with her that she also missed classes and spent time with her boyfriend. Grandpa was speech less.

Although she was his daughter, my grandfather hated Almaz. He was looking for a pretext to force her out of his house. And he did

Her husband was alcoholic. He was addicted to smoking, chewing khat, and gambling" (Eyob, 2014, p.36- 37).

Almaz regularly meet with her drunker boyfriend. Her alcoholic drink made her to steal money and misbehave. This leads to go away from home and quit school. Her boyfriend has been addicted to chewing, drinking and gambling. This implies that such alcoholic and drug abuse in young adults' life are challenges which bring other consequences like misbehaving and quit school due to addiction in which most of the present young adult's experience.

Similarly, in Daniel's Breaking the chain, Munit recognized that street boys whose names were not mentioned were chewing khat when she was searching her brother around Minibus stations.

"Well, I didn't [Munit] come here to reprove him, I'm only here to know his whereabouts."

One of the kids whose left cheek was bulged with khat confirmed that he had gone home. The small boy was also smoking cigarette. Munit couldn't believe that small boys could chew khat. She snatched the cigarette from his mouth, threw it on the ground and crushed it with her foot" (Daniel,2014, p.58).

This dialogue indicates that teenagers have been addicted. The passage also shows that teenagers use substances like khat and Cigarette because of their homelessness that they suffer hunger. In the young crusader also 
Dawud Yibrie, and Haimanot Wassie

workers of the spare parts shop were drinking alcohol and they were intoxicated and attempt to enforce Admassu to drink with them. But they were not homeless and orphans. It implies that even they are not homeless, young adults take alcohol.

"All said “No, No, No!" Following the big 'no', one of them said "just have a couple bottles of beer and we will take a taxi back home. Where is your place? It is too early to go home on Sunday. Don't worry, beer is like food. It doesn't hurt you what is your favorite drink?"

"I never drink alcohol. I don't even know the test of it" everyone laughed again.

"It is then history. You must drink today. What would you like? Beer? Tell us what else you would like to drink," said the big man.

"...His colleagues look like they had many bottles of beer, and they spoke under the influence of alcohol" (142).Here, the drunker workers laughed at Admasu in that a boy who didn't drink alcohol treated as backward .The workers here represent youths that drink alcohol and the attempt to enforce others as Admasu even if he didn't accept their peer pressure. Thus, alcohol and drug abuse is a major theme in the selected novels. The cause of alcohol and drug abuse mostly related to homelessness and hunger in Daniel's novel Breaking the chain and Eyob's novel Behind the invisible bars, whereas in Solomon's novel the young Crusader closely related with enjoyment that results intoxication of users.

\subsubsection{DIVERGENT THEMES}

\subsubsection{CARING FAMILY RESPONSIBILITY AT EARLY AGE AS A CHALLENGE IN YOUNG ADULT LIFE}

Many young adults in Ethiopia forced to shoulder family responsibility because of different problems. Among problems that led teenagers shoulder family responsibility is loss of family in different ways either be death, abandon etc. In Breaking the chain, Munit encounter carrying family responsibility at her early age.

"Munit has been running the shop opened by her mother for quite some time. She had to work hard from dawn dust as she was the bread winner of the family. She was always busy with the shop business, the household chores, and her evening classes." (Daniel, 2014, p.11).

Here Munit a 16 year old girl forced to carry family responsibility. She lost her mother in death and her father abandoned due to the problems he faced in the local people. She runs a routine or tedious task beyond her capacity in that age. This is an issue that many young adult females encounter in Ethiopian family. They carried the burden of family responsibility at their early age.

\subsubsection{HUMAN TRAFFICKING, ORGAN HARVESTING, AND SEXUAL ABUSE}

Human trafficking is an immense problem in Ethiopia. As a result of rampant poverty, large numbers of Ethiopian girls are voluntarily trafficked to other countries such as Sudan and Middle East through illegal desert routes. "The challenge the girls face during the journey is not the end but the beginning of the trauma. Trafficking in Ethiopia has occur internally and externally in the form of adults and child labor and sex trafficking. There were also some reports of organ harvesting and other closely related human right violations, such as exploitative inter country adoption (BetreYaqob, 2006 'Human Trafficking'). Retrieved on March 09, 2017 from http://www.assaman.info/...

This indicates that factors like poverty led young adults to voluntary human trafficking and that result to suffer different challenges during and after journey.

Problem novels in young adult literature fall under the category of contemporary realism, the category of which the most popular young adult novels are a part. A problem novel is one in which the protagonist is faced with a problem (ranging "from physical characteristics of puberty to sexuality, from pregnancy to parenthood, from rape to drugs") that he/she usually confronts on his/her own (Njeru,2013,p. 64).

It signifies that young adult novels portray young adult protagonists struggling problems referred to as problem novels or realistic novels. Ethiopian young adult fictions have features of problem novels or realistic fictions because they portray characters struggle against real experiences of teenagers in Ethiopia. Daniel Negash addressed problems through characters portrayed as victims of sexual abuse, human trafficking, and organ harvesting in that action packed story. For instance the dialogue between Munit and Rihana vividly explain these issues. 
Moments later, Munit asked drying her eyes, "Do you live here, Rihana?"

"Yes, I came here because they made me believe that they'd send me to the Middle East but I'm serving as a sex object. Nobody not even the man who uses me treats me as a human being. Any way I have no option. If I protest...forget it! I've been here for a long time and I'm desperate but I can't do without their help" (Daniel, 2014, p.92).

Rihana planned to went to Middle East. Local human traffickers took her supposing that they would send her. But she stayed under control with other trafficked girls serving as sex objects. They treated as inhuman rather than human beings. Rihana has no option rather she lived in desperate. In the present time many young adults are subjected to such victims who were attempted to go abroad in different desert routes illegally and some voluntarily joined with local traffickers. According to the narrator, the protagonist character Munit herself, her brother, and other boys have been trafficked by local traffickers that the boys were serving at the farm land.

Dred went to the tall person sitting on an elevated mattress working on laptop.

"Are you all right?" Mogie asked.

"Munit kewti has landed here out of the blue," Dred told him.

"You're kidding!...How did she manage to?...Where is she?"

"I put her in the lunacy inducement room."

"How did she find out? ...Have you sent her brother to the farm?"

"Yes! That is what he deserves for the audacity to embarrass the boss publicly."

"Yes, let him suffer there. And, don't also forget that the farm, if successfully run, will soon be an exceptionally profitable business." (Daniel, p. 85).

Ashenafi had been trafficked by Mogie when Ahsenafi was working at Mogie's Minivan as fare collector Addis Ababa to Hawasa. And then they sent him to the farm land where they do business. Munit also trafficked when she tried to found her brother at the compound of the traffickers in secret. Many females and males were forced by the local traffickers to do at the farm land. This was presented as evidence in the novel through the dialogue between Munit and Rihanna (Ibid, pp.93-95). The other issue presented as a problem young adults and children face in Ethiopia is organ harvesting. Local human traffickers harm young adults and children to take some organs. It could be understood from the dialogue of Rihana and Munit that Rihana told to Munit whatever she had seen and heard from the local traffickers.

"I [Rihanna] have heard him telling his boss that the business will be profitable. The idea is to take out organs, particularly kidneys, either from people who voluntarily sell them or forcefully from street children and eliminate them" (Ibid,p.94).

Rihana had heard Mogie talking to his boss that organ harvesting is profitable. She told to Munit that they took out organs like kidney from people who are willing to sell them and from street children forcefully. It is evidence that children and young adults are victims of this inhuman activity. In the same way trafficked young adults are victims of child labor.

[...] "My Lord! Is that boy your brother?"

"So, you've seen him. Where is he? Did they beat him?" Munit asked in loud voice.

"Shishsh..." said Rihana. "He is not here..."

"Where is he then?"

"They resent him to the farm. They gave him tablets that they said would protect him from malaria. The tablets were, however, sleeping pills. I'm sure he dozed off before he even left Gola. He must be in the farm by now".

"Wondering, who Mogie was, Munit said, "But Ashu will not go willingly to another country."

"Munit the last two boys are taken for a totally different purpose. These people have been involved in human trafficking for many years. Now, they have come up with what they call a business diversification plan..."(Ibid, p.94).

Rihana lived for long time with Mogie that he took her everywhere where ever he go and she knew everything what he did with his friends.

This statement shows that the traffickers are doing various illegal activities. Beyond the farm land activities, they forced young people to take organs. They gave them tablets of different kinds to keep the trafficked ones under control.

There is also evidence that Dred and Tsegaye come together with other trafficked girls and a boy. "Dred got off and opened the sliding door of the car. Tsegaye and three girls come out. They seemed relaxed. Then came a terrified boy whose hands were handcuffed behind his back. A well -built tall man pushed from behind...He returned to the 
Dawud Yibrie, and Haimanot Wassie

minivan, ordered the man to take the boy one of the rooms and reminded him to come early in the morning. 'We're taking the boy to the farm!' Finally, he held the girls to the villa" (p.96). Here, they planned to send the boy to the farm land and let him suffer there and the girls at the hiding home serve as sex objects till they sent them if they got the chance. This represents what girls and boys experience in different times. This is a current issue many young adults face in our country. They decide to contact with local traffickers dreaming beater jobs in the Middle East and some others by force become victims of such problems. This indicates that human trafficking, organ harvesting and sexual abuse are prominent challenges of young adults in Ethiopia. These problems are closely related to poverty and seeking better job earnings which are inter related as cause and consequences.

\subsubsection{TEEN PREGNANCY AND ABORTION}

In different circumstances teenagers are at risk to unplanned pregnancy. As teenager is used synonyms with adolescent most of the time teenage pregnancy is defined as pregnancy in women under age 20, approximately. In this research teenage pregnancy is defined as pregnancy under the age of 18 in which 18 is considered as the legal mirage permitted in our country and the average age of giving birth in Ethiopia is estimated to 16 years. One current issue in young adult literature is teen pregnancy. Young adult novels about teen pregnancy can be very influential because teens "want to read about things that are interesting and true" (Donelson and Nilsen, 2003, p. 87). Teen pregnancy is also presented in Ethiopian teenager novels as a challenge of Ethiopian teenagers. Teenagers are vulnerable to unwanted pregnancy due to many problems.

Unintended pregnancy among adolescents represents an important public health challenge in many countries, especially in developing countries. The adolescent unwanted pregnancy is still increasing in Ethiopia (UNICEF, 2006), Population under 18 is about 39 million , of the total population estimated to 85,2 million (MoH,2002 a) and 24 percent girls are giving birth before the age of 18(UNFPA,2005) quoted in Georges Z. Nalenga, 2012, pp.2627).Several studies have shown that marriage of adolescents to became pregnant in Ethiopia rural area is 16 years. Teen pregnancies are of concern because they have negative health and socioeconomic consequences for parents, children, and for the communities as a whole. Moreover, regarding the socioeconomic consequences, adolescent girls leave home and begin conjugal life depending economically on men and adult work; and an early start to child bearing greatly reduces the educational and employment opportunities of women which is again associated with higher level of fertility. Many source indicate that unintended teenage pregnancy is in Ethiopia results abortion both safe and unsafe abortion.

Abortion is defined as a termination of a pregnancy by the removal or expulsion from the uterus of fetus or embryo, resulting in or caused by its death (Sedgh, 2007,p.84). According to the Ethiopian Ministry of Health, abortion accounts for 60 percent. And according to AYRH,2007 over half of 19 million women who annually seek abortion in Ethiopia are under 18 (Georges Z. Nalenga, 2012, p.28). Many girls turn to induced abortions to avoid unintended or unplanned births. Unsafe abortion can result serious negative health effects such as infertility and maternal death. Furthermore, abortion and pregnancy complications are widespread. For instance, in 2008 an estimated 382,000 induced abortions were performed in Ethiopia and an estimated 52,600 women were treated for complications of such abortions (Singh et al, 2010). This implies that teenage pregnancy and abortion are inter related societal problems in which many female teenagers encounter in this post-modern period. As a result, authors of young adult fictions represent themes of teenage pregnancy and abortion to their readers. For instance, Behind the Invisible Bars, Eyob Getahun addressed this issue through characters as presented below. Almaz was Meron's aunt who has a boyfriend and suffers unintended pregnancy at her early age.

"Although she was his daughter, my grandfather hated Almaz. He was looking for a pretext to force her out of his house. And he did. She began to live with her boyfriend who worked as a daily laborer. He earned meager wage. She conceived at the age of 16 and under went unsafe abortion, and she was gravely ill for months...Sadly, however, she couldn't conceive any more, the abortion seriously damaged her uterus. She bitterly resented my father and grandfather. She always blamed and held them responsible for her not having children. She lived in poverty and blamed them for that too" (p.36-37).

Almaz was a 16 years old young girl. She quit school because she fired by her father that she steal money for chewing khat and drinking alcohol. She began lived with her boyfriend and conceived that was unintended pregnancy. Her unwanted pregnancy results unsafe abortion that currently many teenagers in Ethiopia practice. Almaz suffer health problem during abortion and couldn't conceive again that her uterus has been damaged due to 
unsafe abortion she did. This result Almaz to live in poverty that it is also seen in our country everywhere teenagers faced such similar problem.

\subsubsection{KIDNAPPING}

Kidnapping refers to take someone by force to get money from someone (Oxford English Dictionary online, 2017). Some people kidnap children, young adults, and young people even they harm by different cases particularly to get money from someone. In this research, kidnapping is defined in its narrow context that it refers to local kidnapping; take someone away illegally by force to get a ransom. In Behind the Invisible Bars, the protagonist character of the novel Munit has been kidnapped by Fanta where she was begging in the street.

"There were few passerby. None of them were concerned about Fanta dragging Meron, except a young lady who stood to a moment to see what was going on. She thought the huge man and the skinny girl knew each other, father and daughter perhaps; and she didn't dare to say anything to the man.

Fanta opened the door of the truck and threw her on the seat as tough she were a cushion. He then slammed the door."

“I don't want to go!... I don't want to go with you!"Meron shouted nervously.

"[...] Come out!" He held her hand first and carried her out of the truck. Then he gripped her and pulled her into the house. He looked up stairs in to a room which there was only a stool. He made her sit on the floor. He pulled out two pieces of rope from his pocket and first tied her hands behind her back. He then tied her legs together tightly"(Eyob,2014,p.96-99).

Ato Fanta kidnapped Meron where she was begging at her usual place. He was the murderer of her parents in secret. He wants to get money from Almaz that they did the crime to give him his share after all. And Almaz gave him 250,000 birr, but again he needs some more money from Almaz that he took the big risk he did.

He switched on his cellphone and called Almaz. "Hello, good evening Madam;" he said sarcastically, smiling.

"I have been calling you, but your phone was switched off", said Almaz.

"yes, it was ".His face was beaming with satisfaction .

"Why did you want to talk to me?"

"That girl has disappeared." He couldn't hear the distress in her voice.

"you mean the blind girl?"

"yes."

"She is right here with me." He put the phone on laud speaker and brought it near Meron,"say hi to your aunt, Meron."

"Hello," said Meron.

"Are you Meron?” Almaz asked although she recognized her voice, Meron could hear her aunt sigh.

"Yes it is me." 104).

"So, you heard her voice?" Fanta said, bringing the phone back to himself

(Ibid, 103-

Ato Fanta kidnapped Meron and asked Almaz One million birr otherwisehe thought that he would break their promise and would kill Meron.Almaz wanted to keep Meron alive until she was eighteen and could legally inherit her father's villa in DrieDawa. If she did before that, according to her father's will, the villa would be sold and the money sent to an orphanage. Almaz was planning to keep Meron alive until she inherited the villa. Once Meron got the villa, Almaz planned to kill her the same way she had killed her parents so that other people would think it was an accident, thus allowing Almaz to inherit the villa. But here Fanta was becoming an obstacle. She hated him bitterly. She regretted her decision to send Meron out to beg on that day. Obviously, she undermined Fanta. She never thought he was brave enough to kidnap people. As seen from the extract young adults kidnapped by individuals by different problems. It shows that some Ethiopian young adults are victims of kidnapping; as a result, it is represented as a theme in young adult novels. Here, Meron and the kidnapper Fanta represent other children, young adults, and other people kidnapped by and kidnappers who kidnap people to get money from others.

\subsubsection{NEW ROMANTIC LOVE AS A CHALLENGE IN YOUNG ADULTS' LIFE}


Love can be defined in different ways. The 7th edition Oxford advanced learner's English Dictionary defined love as a noun "a strong feeling of affection and sexual attraction for someone" (Sally,w,2006). In the novels under study new romantic love is presented as a challenge in young adult life. It affects the wellbeing and daily activities such as their education. Admasu fall in love with Sofia. He couldn't realize that it was love. He became sleepless and couldn't read properly. Psychologists believe that adolescence (12-18) years old is a particularly hard time for children. They are experiencing all kinds of new challenges in their bodies and in their feelings. As well, they often feel misunderstood as they are struggling to leave behind their childhood and become adults. Adolescence can be a time of both disorientation and discovery. This transitional period can bring up issues of independence and selfidentity, many adolescents and their peers face tough choices regarding school work, sexuality, drugs and alcohol, and social life, peer groups, romantic interests, and appearance tends to naturally increase in importance to sometime during a teens journey toward adulthood(Jeffery J. Arnett,2010,p.363-367).Adolescent experience many challenges due to the physical and biological changes .So, they embark on new issues like new love.

The issue of new love is common in young adult literature. Young adults are interested to read issues directly related to them. Murry (2008) explained that YAL refers to "books written specially for a teenage audience the books usually have a young protagonist and present that young person dealing with issues that other young people all face (belonging, falling in love, or deciding what to do in the future) or issues that young people are afraid they may have to face (violence, drug dependency, alcoholism, being alone, death of a love one, pregnancy, or divorce of parents)" (quoted in Howell ,2012,p.35).Ethiopian young adult novel writers depict young adult characters struggling such mentioned challenges. In 'The young crusader' Solomon Hailemariam depict the protagonist character Admasu fall in new love with Sofia. He struggled to overcome the challenge of the new love he faced.

"The night dragged endlessly. He woke up many times and checked the clock. He even thought about waking up his mother to discuss the issue. He tried to read, but couldn't concentrate. His eyes scanned the pages but he couldn't grasp anything. He saw a hazy picture of the young girl behind the words. Finally, he was dead tired sleep like along in the early morning" (Solomon,2011, p. 6).Admasu neither he sleep properly nor red his text. He visualize the hazy picture of the new loved girl, scanned the passage but nothing is grasped. This indicates that new love affects the adolescent as it is new experience. It hinders and leads young adults to think and disturb unusually.So, they couldn't do their daily activities properly as Admasu encounter. It implies that new love is a challenge in young adults' life if it couldn't treat properly. It could be seen as demonstrated in the following extract.

"Yet he still kept on thinking about the girl. Suddenly the Mathematics teacher approached him and said, 'Admasu, you don't seem attentive.'

"Admasu was taken off guarded."

"Everything is all right, teacher! I was just a bit preoccupied"

"The teacher didn't like the response." (Ibid,7).

Admasu as a new lover couldn't follow attentively even in the class room that everywhere he thinks about her.Even he confused by the new love and he couldn't know whether it is love or not hefeels something new and thinks about her. According to the narrator, in the story Admasu had been felt on the ground around the football play compound scattering his materials holding in his hand and goes to hospital that fact that he saw Sofia in near distance. And also, he was murmuring alone at his uncle's house while he was thinking that he can get Sofia. In effect, his uncle believed that there might be new thing happened to Admassu may be bad spirit and he brought the family priest. This implies that new love can affect the wellbeing of the young adult as well as can disturb family members.

Also, Sofia fall in love with Admasu but both of them couldn't know how to introduce each other and even they bother about whether they loved each other because they were not introduced each other.

"Sofia gave all the good qualities to her imaginary boyfriend. She was determined to approach Admasu, but is still not clear as to how to do it.

Sofia was wondering about what was going on her mind. She didn't exactly know what put her into such a state of mind" (Ibid,50).

This statement indicates that Sofia disturbed by the new love with Admasu. She thinks about him and gave him all good qualities to her lover. She seems confused how to approach him and she didn't know what really put her in such state of mind as she is a new lover. This all signifies that new love is an obstacle in young adult life in which most young adults face. 


\subsubsection{FAMILIAL PROBLEMS}

Many children and young adults are victims of maltreatment in family hood that might be resulted from misbehaving of family members which disturb the wellbeing of young adults and other family members as well. Eyob tried to address maltreatment of young adults as a challenge of teenagers' especially disabled ones like Meron. Family members of Meron disappoint her in that they regularly beat, insult and make her a beggar beside her disability.One day Meron cheated by a petty thief Girum. He took two birr and ninety cents from her pretending to be change coins with birr notes when she was begging at her usual spot. But he took changes by replacing with lottery tickets. Her aunt checked how many she make money and found the lottery tickets. As a result she began insulting Meron and beat hardly.

He didn't want to listen to her. "Shut up! It is been awhile since I punished you."

He rise the belt and feverishly lashed at her back again, then at her legs ...her back again, and her legs again...It lasted about 15 minutes.

They often beat her for no reason.

She considered herself a prisoner for life, put behind invisible bars. Almaz and Goshu sometimes told her how she spent the day and warned her not to do silly as she was being constantly watched (Eyob,2014,p.8-13).

Almaz made Meron to be a beggar near Saint Georges Brewery as her usual spot. They believe that the money she made would help them and every day they follow her and count the money she made each day. Beyond that her aunt, Almaz and her husband Goshubeat Meron without any reason every day. She couldn't escape from them that she was blind. She felt that she is a prisoner lived in dark life. This situation makes Meron feel hopeless.

Likewise, Dnaiel also shows that the young character Munit faced such a challenge in life that her grandmother became a regular drunker. She always insult her and nagging her brother Ashenafi to give her money to drunk. Due to her drunk the old grandmother ley everywhere and the neighborhoods insult Munit.

Today was no different. Woizero Ayelech started with nagging her for money. What could the girl do but give it to her. The old woman went to one of the nearby drinking houses and spent all the money on arekee. By the time she gulped down the lost one, she was already drunk. She pulled herself up with difficulty and somehow managed to make it back to the kiosk. She staggered in, pulled the green linen curtain which served to partition the kiosk in to two and threw herself on the floor.

From there she began raining foul language on her granddaughter.

$[\ldots]$

As usual, Munit did not respond. Rather she closed her eyes and silently pondered, "How long do I have to endure this? "Woizero Ayelech had nowhere to go. Everybody including her elder daughter, Fanwood is also Munit's maternal aunt, had rejected her. (Daniel,2014,p.6-7).

Munitf aced this problem as she takes care of her family at her early age. Here, the old woman is an obstacle to Munit's life. The old grandmother always nagging Munit for money and had drunk alcohol. As a result she disturbs Munit. According to the narrator the old grandmother become misbehave due to the familial problems she faced particularly resulted from the abandon of Munit's father. Many young adults might encounter this problem as they take family responsibility at their early ages. Such familial problems are also causes to other social problems in the family and neighborhoods. For instance,

\subsection{CHARACTER(S) CHOICE IN THE THREE NOVELS}

This sub -section explore how authors of the three novels namely Daniel Negash, Eyob Getahun, and Solomon Hailemaream portray characters to convey major socioeconomic challenges of Ethiopian young adults in this postmodern period. This is not a detail examination of characters but to give insight how the novelists choose characters in the story world to address issues facing the contemporary young adults in Ethiopia.

\subsubsection{DANIELNEGASH'S CHOICE OF CHARACTER(S) IN 'BREAKING THE CHAIN'}

The author portrays characters in a way that visually represent the problems of Ethiopian young adults who suffer various challenges. Munit a protagonist in the novel aged 16 year old portrayed how adolescent females are 
Dawud Yibrie, and Haimanot Wassie

struggling against family burden, poverty, corruption, human trafficking and its consequences like sexual abuse and child labor. As a protagonist character, she struggled against the above-mentioned problems and overcome challenges. The title of the novel 'Breaking the chain' symbolizes the chain of different challenges Munit and other characters face in the story. These were poverty, and the chain of illegal traffickers and corruption that illegal officials and individuals make and harm young adults and the society as a whole in this postmodern period. Characters are portrayed as victims of human trafficking including Munit herself the protagonist character, Rihanna, Ashenafi, and others were mentioned. Some charters also portrayed as alcohol and khat addicted, such as the boys in the streets and Munit's grandmother to revel the main issues of young adults.

Thus, the author's choice of characters in the novel such as Munit a 16 year old woman, Ashenafi,13 year old boy, Rihanna 17 year old woman, characters represented as street boys, the trafficked girls and boys helped him to represent issues of young adults as it is the main feature of contemporary young adult fictions.

\subsubsection{EYOBGETAHUN'S CHOICE OF CHARACTER(S)IN 'BEHIND THE INVISIBLE BARS'}

Eyob in Behind the Invisible Bars' used a protagonist with whom many young adults would identify easily. Meron and Girum were the two protagonists embarked on difficult conditions. The author has used protagonists who were experienced different challenges what most young adults in Ethiopia face in this postmodern period. Meron and Girum, are blind and homeless orphans respectively. Meron lost her parents in secret murder and her sight too. It has been done by Almaz and Ato Fanta that Almaz would give him two hundred fifty thousand birr to Fanta if he killed Meron's parents because Almazplanned to inherit all the property. Unfortunately Meron left lost her sight. Her aunt Almaze and her husband Goshu went to Addis Ababa and forced Meronto be a beggar in the streets near Saint George Brewery and near the Holly Savior Church as her usual spot. They follow her at a closer distance and every day they chalked the money she made at begging, began insult, beat her and even they let her sleep without enough food. This has been shown in the dialogue between Meron and Girum as demonstrated bellow.

"When was that?" Girum asked.

"It was about five years ago...As soon as we arrive here, they bought the house we're living in now. I think they bought a house away from the main road because they wanted to hide from people who knew them...When we began to live in that house, Almaz transformed into devil. She began insulting and beating me. It was surprising to me that she had succeeded in concealing her bitter hatred for me more than six months. Her and her husband's true personality surfaced...They didn't give me enough food. They let me sleep on the floor. They beat me for reasons that were not worth-mentioning at all" (Eyob,2014, p.4).

It is what Meron has suffered in her life mistreated by her own aunt Almaz. The author takes these characters from Dire Dawa to Addis and makes the blind girl as a beggar.

The author's statement seems to convey that people like Almaz harm disabled young adults and it highlights currently people give more value to money than human beings. The female protagonist Girum brought up from Adama town to Addis Ababa who lost his mother dead of cancer and his father has dead after two months. He became an orphan and began to live in the street in Addis Ababa with his friend Bedlu. He always suffer hunger because he did nothing in the streets unless they beg and steal from people around minibus taxis during rush times. People insult and beat them. One day his friend Bedlu steal a wallet and caught red handed and become prisoner. That was the time Girum lives in dark that Bedlu was brave at begging in the street.

The depiction of two characters Meron and Girum as orphan, homeless, disabled, beggars, vividly describes the many of adolescents lived in the street. It create visual image of children and young adults suffering in such conditions. The portrayal of characters like Almaz, Fanta, and Goshu as greedy and unpunctual represent some people who gave more value to money than human being. This is the author's intentional choice of characters as a style that helped him to address the issues of postmodern adolescents and the conditions they live in.

\subsubsection{SOLOMON HAILEMARIEAM'S CHOICE OF CHARACTER(S) IN 'THE YOUNG CRUSADER'}

Solomon Haliemariam portrays a young character Admasu as a 12-grader student. The title of the novel is derived from the protagonists experience and successes. Admasu struggled corruption, new love and family problems and overcome these problems being hard worker and hope full. The author's choice of this young adult 
protagonist help him to address issues of young adults readers could understand easily hence the protagonist can be identified as an Ethiopian.

Admasu confronted the corrupt director of his school and get admiration from every boy.

Admasu fall in love with Sofia. He became confused and couldn't know what he felt.He began to discuss with his mother about the issue. At the same time his father had been mentally ill. His mother told him that she has decided to sell the house where they live in because the doctors told her that Seyum should be treated abroad in India. So Admasu forced to live with his uncle Ato Nigatuand continue his education. It was difficult to him learning in such conditions. His mother told him that they would suffer scarcity of money after they come back. Having this Admasu decided to work something and earn money to help his mother not to fall in poverty waiting his admission to university. He employed as a supervisor after working in a small internet café earning very small salary.in the spare parts shop, the workers were dishonest and made him victim of intrigue. This result Admasu's imprisoned. But finally he become free after investigation, and gate his lover, and his parents come abroad and scored the highest point at his school.

The author presents the reader with a protagonist who struggles against all odds to achieve that which he always desired in life. The author gives his protagonist such a hard start in life with a view of appealing to the readers with similar issues. He seems to suggest that like Admasu is not ashamed of his new love, discussed with his friend and his mother, and he his critical thinker struggle corrupt did around him, the way he treats his challenges and continue his education are the results how he become self-sufficient that readers should also follow suit. The author suggests that the predicaments that befall him are not unique. It is the author's way of telling them that others have had difficult times in life and made it. They too can borrow a leaf from Admasu's life.

\subsection{NARRATIVE ASPECTS AS A STYLE IN THE THREE NOVELS}

Authors of literary fictional works use different narrative styles that they chose them fit to their objectives and issues they want to convey. The narrative aspects involve the use of point of view, narrator, tone, imagery and other language features employed in a given fictional work. These elements would help novelists to tantalize and to create images in the minds of the targeted audience to whom the literary product is aimed to convey messages.

The next sub-section will explore how the three authors the selected Ethiopian young adult novels employ narrative aspects such as point of view and choice of narrator to help them to unfold problems facing Ethiopian young adults today.

\subsubsection{POINT OF VIEW AS A STYLE IN THE THREE SELECTED ETHIOPIAN YOUNG ADULT NOVELS}

A work of art, more so a story has narration, which is the process of presenting a narrative. Close linked to narration, is narrative point of view which determines in whose perspective the story is told.

Point of view refers to the speaker, narrator, persona, or voice created by authors to tell stories, present arguments, and express attitudes and judgments. Point of view involves not only the speaker's physical position as an observer and recorder, but also the ways in which the speaker's social, political, and mental circumstances affect the narrative (Robert Jacobs, 2003, p. 192). This implies that the choice of the narrative point of view and the sociopolitical and mental conditions in a narrative play crucial role in a given literary genre. A narrative could be told from first person point of view, second person point of view, third person point of view of and it might be multiple points of view. Thus, the researcher contends that it is significant to identify the modes of narration in analyzing and interpreting young adult novels under study.

Young adult novels have commonly used a first person point of view in which the adolescent character takes an "I" position in the story, and thus all the events in the text are presented from a single point of view. Even though they used first person point of view, they also used third person point of view (Dnelson and Nileson,2001). The author, depending on the message that needs to be passed across, choses the narrative perspective he /she deems fit.

Moreover, to give credence to what the characters exposed through the use of the third person narrator go through, the author makes use of dialogue and internal monologue. Dujardin (2004) defines interior monologue as "the uninterrupted flow of thoughts going through the character's being, as they are born, and in the order they are 
Dawud Yibrie, and Haimanot Wassie

born, without any explanation of logical sequence and giving the impression of 'raw' experience(p.89).Thus there is a close relationship of what characters say and what goes on in their mind. The exposed thoughts reflect on the repressed ideas. The characters search for the meaning of their live through dialogue. Tormented by anxiety and unable to rescue themselves from fixed positions such as perpetual poverty, alienation, delusion etc., characters try to find a solution to them both in their mind and interaction with other characters (Ibid, p.49).These mentioned features would help the author to address and report what is going on the characters and their internal feeling, their interaction with other characters and to vividly describe the sufferings and their discussions to overcome challenges.

The choice of the narrator in young adults' literature is crucial since more often the narrator plays a crucial role in forming a link between a work of art and the reader. It is the perspective of the narrator that determines who and what the readers look at in a story, how they look at it, what details they focus on and for how long they will look. It is the narrator who organizes the reader's view and opinion of issues by being the force at the center of the narrative i.e. controlling, shaping and guiding the action there in

Depending on an author's vision and mission, the choice of the kind of narrator to use is paramount. The narrator sustains the narrative and gives the readers a voice of explanation for the events that take place in it. In addition, narrators present their own perspectives upon which they interpret the material in a narrative both characters and events. An author may also, depending on the message he wants to put across, be forced to choose his narrator on gender and age basis. There are those who would like to use "women or girls as their narrators while others choose to use men or boys. Some may be forced to use adults, others youth and still others may opt for children as their key narrators" (Njeru, 2013, p.45). Therefore, authors employ narrator based on the issues and message they want to address the targeted audiences. Perspective matters in storytelling. Authors of fictional works employ among the following modes of narration.

There are six key terms used in the study of narrative view point: first-person, second-person, third-person, third-person objective, third-person limited, and third-person omniscient. Each term refers to a specific mode of narration defined by two things: the distance of the narrator from the story (the pronoun case) and how much the narrator reveals about the thoughts and feelings of the characters (narrative access). Robert Jacobs (2003) summarized modes of narration as:

First-Person Narration - In this mode, the narrator is usually the protagonist or central character in the story. But even if this character is not the protagonist, he or she is directly involved in the events of the story and is telling the tale "first hand." First-person narration is easy to identify, because the narrator will be telling the story from "I's" perspective. Readers should watch for the narrator's use of first-person pronouns- "I, me, my, our, us, we, myself, and ourselves," as these will usually indicate that the passage is narrated from first-person perspective. Remember, with this skill readers are trying to identify the perspective of the narrator; therefore, one must ignore the dialogue of characters (indicated by "quotation marks") and solely focus on narration, otherwise one is not analyzing the narrator's point of view.

Second-Person Narration-As it is generally awkward for a story to be narrated from "your" perspective, this mode of narration is not used very often in narratives and stories. There are some exceptions, however, and secondperson perspective is the primary mode of narration for adventure books and similarly styled writings. More frequently, directions and instructions usually narrated from second-person perspective. In most cases, directions will be written in short imperative sentences, where the implied subject is "you." But even when "you" is not explicitly stated, it is understood that "you" are the subject of directions and instructions.

Third-Person Narration-With this mode of narration, the narrator tells the story of another person or group of people. The narrator may be far removed from or not involved in the story, or he or she may be a supporting character supplying narration for a hero. Frequent use of "he, she, them, they, him, her, his, and their" by the narrator may indicate that a passage is narrated from third-person perspective. There are three distinct modes of thirdperson narration: objective, limited, and omniscient. Which mode the narrator is using is determined by a single variable- how much the narrator accesses the thoughts, feelings, and internal workings of the characters and shares them with the reader through narration. Characters' feelings and motivations can be inferred and understood through their behavior and dialogue in each of the three modes of third-person narration; however, in determining which mode the narrator is operating, readers should be concerned with finding instances where the narrator explicitly reveals a character's thoughts or feelings.

Third-Person Objective Narration is a mode of narration, the narrator tells a third-person's story (he, she, him, her), but the narrator only describes characters' behavior and dialogue. The narrator does not reveal any 
Socioeconomic Problems of Ethiopian Young Adults as Reflected in Three Selected Ethiopian Young Adult Novels in English

character's thoughts or feelings. Again, readers will be able to understand characters' thoughts and motivations based on characters' actions and dialogue, which are narrated; however, the narrator will not explicitly reveal character's thoughts and/or motivations in narration.

Third-Person Limited refers to the narrator's perspective is limited to the internal workings of one character. In other words, the narrator reveals the thoughts and feelings of one character through explicit narration. As with objective narration, readers may be able to infer characters' thoughts and feelings based on the behaviors and dialogue of those characters, which are narrated, but the narrator also directly reveals the central character's internal perspective.

Third-Person Omniscient is another perspective. In this mode of narration, the narrator grants readers the most access to characters' thoughts and feelings. With third-person omniscient narration, the narration will reveal more than one character's internal workings. (pp.191-192).

More common than the omniscient and dramatic point of view is the limited third person or limited omniscient third person, in which the author concentrates on or limits the narration to the actions and thoughts of a major character. (Ibid, p.199).Thus,it is the author's choice which mode of narration is appropriate to the story be told to transcend the themes in the story.

In 'Breaking the chain', limited omniscient narrator speaks how Munit has struggled the multifaceted problems. The speaker in this novel presents issues through the protagonist character interacting with other characters through dialogue that enables the reader to identify with the happenings. For instance, the author took Munit to the local traffickers' compound searching her brother Ashenafi and made her trafficked. Then she met with Rihanna while she came to her to give food in her room. This brings a broad communication between Munit and Rihanna. The dialogue between them (pp.93-95) has presented the issues of human trafficking, organ harvesting, and sexual abuse that young people encounter. Through the narrator, the issues of poverty, corruption, human trafficking, sexual abuse, organ harvesting, child labor, alcohol and substance abuse are highlighted. The story unfolds through the eyes of the narrator that the protagonist character has interacted with other characters in different ways.

The author also makes use of images, or imagery, as a primary underlying structure in language and mind. It is a basic element in communicating and creating, an integral part of thinking, speaking, listening, reading, and writing (Njeru,2003, p.45). Images point to the nature of our human condition, to the experiences we remember, visualize and come to understand in the acts of reading and writing. Every detail of Munit's life as she comes of age and other characters reflected through visual images in the mind of the reader. These images are very striking and no reader can miss them from the powerful and evocative writing style that Daniel deploys in this novel.

"...So, she [Munit] ran to the gate to save her life. The dog chased her and caught the bottom of her trousers which tore easily. She turned back, and ran towards the minivan.

"Blackie! "She heard a man calling. "Good boy, Blackie!"

Blackie gave up the chase instantly and started wagging its tail, waiting it looks, for the masters order ...Munit was standing between the black hound and Dred. Still she felt relieved, at least,for the moment...Dred was in front of her with a long chain in his hand.

"Kewti, thank you for taking the initiative to come here. You saved us a lot of trouble I'm sure Blackie has scared the pants off you, hasn't it?...Hope you're fretting about what is going to happen to you. Don't worry a little drug will help you calm dawn.

[...] Dred scarfed at her and pulled out a small plastic bag from his pocket, sniffed it until she sneezed" (Daniel,2014, p.83).

This extract may create a visual image how Munit was caught by 'Blackie'. The dog tore her trousers and the voice of the man calling the dog might also create something in the readers' mind that she realized that she fall under control by Dred.

The purpose of this section was to highlight how and why the writing style of this author leads to an intense evocation of some themes as outlined in 'Breaking the chain'. Through the use of imagery and the limited omniscient third person narrator, the author is able to create a strong connection between his readers and the text. Even though the story is full of tragic events, the story ends in an optimistic note that Munit overcome the obstacles she has faced.

In 'Behind the Invisible Bars', the author chose third person point of view. The narrator is omniscient third person (all knowing) narrator. The speaker narrate as actions go on and the inner thoughts of characters and reports events as an external observer. The author chose omniscient narrator intentionally to vividly address the challenge of the major characters and other characters encounter through actions and in their mind thoughts. The author used 
Dawud Yibrie, and Haimanot Wassie

long dialogues among characters and flashback through which characters shared each other's experience. Meron and Girum are the major characters in the novel. The author took the two characters from Drie Dadwa and Adama to Addis Ababa respectively. Meron was from wealthy family who have construction site and Girum was from poor family who live in hand to mouth that his parents have small income.

The story begins when the narrator speaks Girum was sitting in the street at the evening. "It was around six o'clock in the evening. Girum was sitting on the steps of the stairs in front of Addis Ababa Tegbaried Poly Technique college. A few meters to the right was the gate of Saint George Brewery. Up ahead---men, women, young, old, slim, stout, tall, short, dark, fair---crowed the pavement" (Eyob,2014,p.1).This story can create a visual image of Girum and how the people were crowed the pavement since it was rush hour.

The author has used visual image which vividly represent how Girum suffer challenges in the street and Girumas a homeless orphan sitting in the street listening the rumbling of his stomach. A reader can also visualize the image of Munit begging at her usual spot sitting in the street near the Holly Savior Church suffering the horrifying hot sun at midday.

"Girum carelessly gazed at the stream of passerby, resting his elbows on his knees, and cupping his cheeks in his hands. Unlike most of the people in the street, he didn't have a home to rush; neither have a family to miss. He was a homeless orphan. In fact, at the moment, he was not worrying about home or a family. Rather he was listening to the rumbling of his empty stomach. He didn't eat the whole day. He carved for something to eat" (Ibid,2). The reader can create a picture of a miserable boy resting his knees and cupping his cheeks in his hands. The author in this statement had tried to create the image of the boy as a homeless orphan experiences hunger and as the same time to address the mind thoughts of this miserable boy.

"Rat poison!" a street vendor announced with an ear piercing voice.

"Suddenly, Girum thought of committing suicide.

Embittered and hungry, he asked himself, 'why do I need to live?...Why?... must bring this miserable life of mine to an end'(Ibid,p.2).This also shows that how the author is intended to take readers insight in to the mind of the character. Furthermore, the following extract supports the novelist's use of omniscient narrator.

'He must be a sad and lonely person like me[Meron].I could feel it...I could feel it. Of course, he must have a better life than I do. He can see and he is free, but he must be miserable. There was unhappiness and bitterness in his voice...will he ever come back to me?...I wish...' she kept on thinking and could not sleep until midnight.(Ibid,p.17).Meron was thinking about Girum. He had asked her money after he had cheated her two times took her coins changing by outdated lottery tickets. The omniscient narrator intervene the internal thoughts of Meron as she was thinking that Girum might be a miserable person like her even he is free and not disabled.

The author tried to create natural images on readers' mind using nature as presented here with.

"A big tree growing a few meters from the gate of the Holly Savior church cast its shadow on Girum, Meron, and a couple of other beggars. It shielded them from the scorching early afternoon sunshine" (Ibid,p.43).Any reader could not miss this natural image of the big tree and the beggars under the tree that it casts its shadow on beggars sitting near it.

The story ends with an optimistic note that Girum make Meron to escape from Fanta. In effect, Meron escape from the invisible bars.

"Girum's face beamed. He held Meron's hand. She pressed his hand affectionately."

"Now I can never imagine life without Girum. He's my light."She smiled sweetly.

"You too are my light," Girum said passionately, looking down at her with love."

"Although she couldn't see his eyes, she felt his profound love for her."(Ibid,p.146).This story shows that the disabled ones like Meron needs help from other and disabled ones also can help others .According to the narrator Meron advised Girum to work something and gave him some coins and escape from being a beggar and living in miserable conditions. Poverty is not hereditary that it could be treated by working hard this was the advice of Meron to Girum. He started work as fare collector in minibus taxis. Then he did his promise he had had to Meron, made her free from the devilish people Fnata and Almaz.

Through the use of imagery, omniscient narrator, and dialogue as a style the author highlights characters facing poverty, disability, teenage pregnancy and abortion, alcoholism, maltreatment of young women, homelessness and loss of parents, and kidnapping that characters faced as the story go on. These challenges are what most adolescent or young adults face in this postmodern period. 
The use of omniscient narrator, dialogues and imagery as a style play a crucial role to the author to reveal detail events about characters.

In 'The Young Crusader' Solomon Hailemarieam chose third person narrator who is omniscient narrator. Admasu as a central character of the story interact with other characters. The narrator address events through the interaction of the central character with other groups and discussed with friends and his mother. As anew lover, Admasu struggled with himself, and daydream about his loved one everywhere even in the class room. The following extract shows how the narrator reports the mind thoughts of Admasu.

"Admasu was engrossed in thinking about the looming disaster. He spent the whole night trying to find a solution to the problem. He didn't want to consult his uncle as he thought it would be futile" (115). Admasu often thinks about the problem he faces how to solve it and he thought that it might be valueless if he told to his uncle.

In addition to the protagonist character the narrator revealed the thoughts and emotions of other characters in this story. As Sofia had fallen in love with Admasu, she was thinking about him and daydreamed frequently.

Sofia has been thinking about Admasu for quite some time. She often dreamed about him.She imagined walking beside him as everyone whispered, "who is the guy with Sofia?" She kept walking with pride. Those who didn't belong to Admasu's school didn't of course know about his good deeds. So, they would ask her, "Sofia, who is the guy you were walking with yesterday?" She would answer that he is her father's hero and a friend.

No, instead she would say, "He is my boyfriend or my hero!'When she mentioned to herself the phrase 'my hero' she shivered.

She thus continued to imagine different scenarios (49).

This extract shows the author tried to infer the feeling of Sofia and other characters. So, the narrator intervene in the character's mind thoughts.

So, the narrator is omniscient narrator. Thus, the author chose this omniscient narrator to reveal how Admasu and Sofia have been entirely affected by the problem they faced. The author revealed challenges of poverty, new love, corruption as themes in the novel. The title of the novel symbolically represents the success of the central character who struggle the challenges he has faced as coming of age assuming self-actualization/discovery.

As seen above in the discussions, third person narrative point of view is employed by the authors to address the challenges of the central characters and other characters in the novels. This implies that authors use of third person point of view and omniscient narrator help them to show how characters represent the challenges of the present young adults as conveyed in the story world. The next sub-section presents similarities and differences exist among the novels under question.

\subsection{COMPARE AND CONTRAST ANALYSIS OF THE THREE NOVELS}

In order to fully appreciate and understand the impact young adults' literature have on presenting the contemporary young adults' problems in Ethiopia, it is necessary to compare and contrast aspects in the three novels under study and how the protagonists negotiate round the challenges they encounter. There is a difference in the way the writers have presented the challenges of the young adults in contemporary Ethiopia, similarities lay in how the protagonists deal with these challenges. Among the similarities, young adults in Ethiopia in the selected novels are represented as being more resilient and focused. The three authors focus on the young adults as protagonist in their novels. Munit, Meron, Girum, and other characters lose their parents at an early age and have to negotiate through the challenges in life with little or no assistance from the surviving relatives. According to Donelson and Nielsen (2001) the loss of parents at an early age is a characteristic of the young adult literature so that the reader focuses on the young adult character.

Whereas, Admasu, in Solomon's 'The young crusader' portrayed as separated from family for some time even reunite after three months. All characters in the three novels encounter predicament after predicament but just when they are about to give up, help comes and their stories end at an optimistic note.

Authors of the three novels understudy had employed their own styles of presenting issues to their reader such as character choice, point of view and imagery .In 'Breaking the Chain', Daniel Negash has used a female character16 years old named Munit to address the current socioeconomic problems facing young adults in Ethiopia such as poverty, human trafficking, family problem, caring family responsibility at early age, organ harvesting, homelessness and loss of parents, alcoholism and drug abuse. Whereas Solomon Hailemarieam, in 'The Young Crusader', had Chosen a 12 graded young boy as a central character struggling corruption, and new love. Whereas Eyob presents 
Dawud Yibrie, and Haimanot Wassie

two young adults namely Girum and Meron who are male and female characters respectively. He portrays young adult characters suffering homelessness, poverty, disability, teenage pregnancy and abortion, alcoholism and drug abuse, corruption, and kidnapping as challenges of young adults'. The three authors used third person point of view and omniscient third person narrator to address issues of young adults through dialogues of different characters in the story world. In Daniels' 'Breaking the chain' the narrator is limited omniscient whereas in Eyob's 'Behind the invisible bars' and Solomon's 'The young crusader' narrator is omniscient (all knowing) narrator.

Using third person narrator, setting, and character choice is a common feature among the novels that has a crucial role in the story world to relate how the contemporary Ethiopian young adults encounter such problems in their day today activities.

The parallel themes identified in this study were poverty, corruption, alcohol and drug abuse, homelessness and loss of parents in which most young adults face. On the other hand there are divergent themes that represented in the selected novels as prominent challenges. Among these, human trafficking, , organ harvesting sexual abuse, family problem, new love, kidnapping, teen pregnancy and abortion , caring family responsibility at early age have been identified.

\section{CONCLUSION AND RECOMMENDATIONS}

Young adult literature is a literature which is written for and marketed to young adults. Ethiopian young adult novels in English have started to publish following the lunching of the Burt Awards in African literature. CODE is an NGO which encourage African writers for young adults to motivate young writers and create a love of reading among African young adults. The Burt Award is given in African countries Tanzania, Ghana, Ethiopia and Kenya. Ethiopian Writers who won the Burt Award in the last years published their novels by CODE-Ethiopia. These Young adult novels often reflect the experience and the concerns of young adults. The socio economic problems of Ethiopian young adults refers to the social and economic difficulties that challenge the lives of young adults, such as poverty, corruption, alcohol and drug abuse, homelessness and loss of family, teenage pregnancy and abortion, family problems, human trafficking, sexual abuse, organ harvesting, and caring family responsibility at early age.

The major themes of the three novels identified in this study more or less agree with these points identified in the review of literature section. Themes of corruption, homelessness and lose of parents, poverty, alcohol and drug abuse are the major parallel themes represented as challenges of Ethiopian young adults in the novels. Themes of caring family responsibility, teenage pregnancy and abortion, kidnapping, new romantic love, human trafficking, sexual abuse, and familial problems are divergent themes represented as problems facing Ethiopian young adults. In Daniel's 'Breaking the chain' corruption, human trafficking, and sexual abuse are closely related to poverty. Other problems such as alcohol and drug abuse are related to loss of parents and homelessness and vice versa. Characters including the protagonist character characters are portrayed as suffering poverty, corruption, human trafficking, and loss of parents. And other characters suffer alcohol and drug abuse, sexual abuse, child labor, and victim of organ harvesting.

In Eyob's 'Behind the invisible bars', homelessness, loss of parents, alcoholism, teenage pregnancy, mistreatment of young adults, and abortion are presented as the major challenges of Ethiopian young adults. On the other hand, Solomon's 'The young Crusader', conveys corruption, new romantic clove and, poverty are the main problems which represent the contemporary Ethiopian young adults.

The three novels, in addition to the thematic parallels and divergences described above, have some other striking resemblances and differences. They all have Ethiopian young adult characters as central character under the age of 18 years old. The point of view of the stories told is in third person point of view in which a third person narrator told the stories of young adults.

The other thing that makes the novels share the same quality is that the story revels the young adults in Ethiopia are represented as resilience even though they are surrounded by social and economic devils. As a result all the novels end in an optimistic note that the protagonists overcome those socioeconomic problems.

In addition to the above-mentioned similarities, authors of the three novels choice of characters, setting, narrative point of view, and imagery employed are identified as a style to reveal the major socioeconomic problems challenging Ethiopian young adults. Thus, the Ethiopian young adult novels are among others which vividly represent the predicaments of Ethiopian young adults. 


\section{SOURCES OF FUNDING}

None.

\section{CONFLICT OF INTEREST}

None.

\section{ACKNOWLEDGMENT}

None.

\section{REFERENCES}

\section{Primary Sources}

[1] Daniel Negash. (2014). Breaking the Chain. Addis Ababa: CODE-Ethiopia.

[2] Eyob Getahun. (2014). Behind the Invisible Bars. Addis Ababa: CODE-Ethiopia

[3] Solomon Hailemariam. (2011). The Young Crusader. Addis Ababa: CODE-Ethiopia.

\section{Secondary Sources}

[1] Ambróziová, A. (2011). "Social Issues in Contemporary African-American Young Adult Fiction". (Diploma Thesis). Department of English Language and Literature. Masaryk University.

[2] Aronson, M. (2010). Exploding the Myths: The Truth about Teens and Reading. London: Scarecrow Press.

[3] Aschalew Kebede. (2015, March12). Book review of 'The Young Crusader'. Addis Admass.

[4] Beaty,J. , Both, A. \&Hunter, J.(2002).The Norton Introduction to Literature(8th ed.).New York: London.

[5] Braun, V. \& Clarke,V. (2006).Using thematic analysis in psychology. Qualitative research in psychology,3(2), pp.77-101.

[6] Bayleyeng Ayalew. (2011). "Realism in SahleSellassie Brhane Mariam's Warrior King and The Afersata". (un published MA thesis). Addis Ababa University.

[7] Bowen, G. A. (2009). Document Analysis as a Qualitative Research Method. Qualitative Research Journal, 9(2), 27-40.

[8] Cart, M. (2005): From Insider to Outsider: The Evolution of Young Adult Literature. Voices from the Middle, 9(2), 95-97.

[9] Cart, M. (2010). Young Adult Literature: From Romance to Realism. American Library Association.

[10] Christenbury, L. (2000). Making the Journey: Being and Becoming a Teacher of English Language Arts (2nd ed.). Portsmouth, NH: Boynton/Cook.

[11] Creswell,J.W. (2007).Qualitative Inquiry and Research Design: Choosing Among Five Approaches. London and New Delhi: SAGE Publishers.

[12] Donelson, K., \& Alleen Pace N. (2005). Literature for Today's Young Adults (7th ed.). New York: Pearson Education.

[13] Donelson, K., Blasingame, J., Blasingame, N., Don,L.F. \& Nileson, A.P.(2013).

[14] Literature for Today's Young Adults (9th ed.). Pearson Education.

[15] Frey, Charles H., \& Lucy, R. (2004). Classics of Young Adult Literature. Upper Saddle River, NJ: Pearson Education.

[16] Griffths, G. (2000). African Literature in English: East and West. London: Pearson.

[17] Howell, Robyn. E. (2012). Yong Adult (YA) Literature: Details and Trendsetting. (MSC

[18] Thesis). Warrensburg: University of Central Missouri.

[19] Jacobs, Henry V. (2003). Literature: An Introduction to Reading and Writing (2nd ed.). The City University of New York: Prentice Hall. 
[20] Kanka, B. (2014). Explore International Research Journal Consortium. International Journal of Management and Social Sciences Research (IJMSSR),3(1),2319-4421.

[21] Kaplan, J. (2010). A Review of Research on Young Adult Literature. (Doctoral Dissertations (2008-2009)). The ALAN Review. Pp. 54-58.

[22] Koelling, H. (2007). Best Books for Young Adults (3rd ed.). USA: American Library Association, Google Books. Web. Accessed December 15, 2016.

[23] Milner, Joseph O' Beirne. \& Lucy, F.M. (2002). Bridging English. New York: Macmillan Publishing Company.

[24] Mo FED. (2012). Evaluation of UNICEF on Adolescent/Youth Development in Ethiopia (2007- 2011). Addis Ababa: Ethiopia.

[25] Molvaer, K. (1997). Black Lions: the Creative Lives of Modern Ethiopia's Literary Giants and Pioneers. Lawrenceville, NJ08648: the Red Sea Press. Inc.

[26] Nalenga, G. (2012). Causes of unintended pregnancy among adolescents in Addis Ababa, Ethiopia. (MA Thesis). Norwegian University of Life science (UMB) department of plant and Environmental science.

[27] Nichols, K. M. (2005). Teen pregnancy in Young Adult Literature (MA thesis). Iowa: Iowa State University. online: Retrieved fromhttp://lib.dr.iastate.edu/cgi/viewcontent.cgi?article=17165\&context=rtd

[28] Njeru, k. (2013). Young Adults' Literature as a Tool of Change in the Lives of Young Kenyans: A Case Study of Never Say Never by Anthony Mugo and The Delegate by Edward Mwangi (Unpublished MA Thesis). The University of Nairobi.

[29] Orana, M. (2003). Developing a Love of Reading: Text Analysis workshop. EBS publishing.

[30] Wchmeier, S. (2006). Oxford Advanced Learner's Dictionary(7thed.). Oxford University Press.

[31] Priya, A. P. (2016). Young Adult Fiction: A bailiwick in Recent Fictions of India. Global English-Oriented Research Journal (G E O R J),1 (4),153-160.

[32] Reed, Arthea J. S. (2000). Reaching Adolescents: The Young Adult Book and the School. New York: Holt, Rinehart and Winston.

[33] Sedgh, G., Heshaw, S., Singh, S. Bankole, A. \&Drecher,J. (2007). Legal abortion worldwide: incidence and recent trends. International family planning perspectives. Guttmacher Institute, 33 (3), 106-116 [online] retrieved March 19,2017 from https://www.guttmacher.org/journals/ipsrh/2007/09/legal-abortion-worldwideincidence-and-recent-trends

[34] Sharma, Gopal. (2012). The Issue of Universality and Contemporary Ethiopian Fiction. Science, Technology and Arts Journal, 1(2),72-75

[35] Singh, S.T., Fetters, H., Gebreselassie, A., Abdella,Y., Gebrehiwot, S. Kumb , \&S. Audam.(2010).The Estimated Incidence of Induced Abortion in Ethiopia, 2008. International Perspectives on Sexual and Reproductive Health, 36 (1),16-25.

[36] Stover, Lois T. (2004). Young Adult Literature: The Heart of the Middle School Curriculum. Portsmouth, NH: Boynton/Cook Publishers.

[37] UNICEF. (2013). Policy brief: Increasing Investment in Addis Ababa, Ethiopia. Adolescent youth development program. UNICEF.

[38] Watson, V. (Ed.). (2001). The Cambridge Guide to Children's books in English. New York: Cambridge University Press.

[39] Yared Gebremeden. (2015, December 26). "Ethiopia: Some Global Issues Facing Our Youth Today". Ethiopian Herald. 